\title{
Challenges and perspectives for human activity in Arctic coastal environments - a review of selected interactions and problems
}

\begin{abstract}
The currently-observed increase in human activity in the Arctic accelerates the negative impact on the environment as well as increases the risk of threats to mankind itself. This paper reviews and summarises a selection of studies on the interaction between humans and the environment in the Arctic coastal zone, which is impacted by a warming climate and associated geohazards. The paper presents a general description of human presence in the Arctic, identifies and describes the processes that are threatening the infrastructure, and the anthropogenic processes that have a negative impact on the Arctic. It considers the possible future economic opportunities, and presents the sustainable requirements for modern human activity in the Arctic. The paper demonstrates the urgent need to develop a common, Arctic-wide strategy based on sustainable development. The time has come to change human perception of the Arctic because, in the near future, it may be considered as a refuge for climate change refugees.
\end{abstract}

Keywords

Arctic settlements $•$ climate change $\bullet$ geohazards • environmental changes • anthropogenic impact • arctic sustainability

(C) University of Warsaw - Faculty of Geography and Regional Studies

\author{
Marek Wojciech Jaskólski $\mathbb{C}^{1,2,3}$ \\ 'Institute of Geography and Regional Development \\ University of Wroclaw, Poland \\ 2Leibniz Institute of Ecological Urban and Regional \\ Development, Environmental Risks in Urban and \\ Regional Development, Dresden, Germany \\ ${ }^{3}$ Interdisciplinary Centre for Ecological and Revitalizing \\ Urban Transformation, Görlitz, Germany \\ e-mail: marek.jaskolski@uwr.edu.pl \\ Received: 20 May 2020 \\ Accepted: 30 September 2020
}

Introduction

The Arctic area, according to different definitions, is that area north of the northern polar circle of $66^{\circ} 33^{\prime} \mathrm{N}$, and bounded to the north by the July isotherm of $10^{\circ} \mathrm{C}$ which is a crucial determinant for the processes described in the text (Hotez 2010; Vavrus et al. 2012). This area contains among the most vulnerable ecosystems in the world. In the context of global climate change, it is seen also as a source of information for predicting environmental change and methods of reconstruction at moderate latitudes (Bowden 2010; Francis \&Vavrus 2012). The Arctic landscape is currently undergoing experiencing changes due to accelerated environmental and anthropogenic processes that both pose risks and offer potential for human activity in the Arctic (Hjort et al. 2018; Karjalainen et al. 2019). An estimated 3.6 to 4 million people live in the Arctic area (Bogoyavlensky 2004; Hjort et al. 2018) and human activity is concentrated mainly in the coastal zone, where the strongest anthropogenic interactions with the environment occur (Forbes 2011). Over the last 30 years, the Arctic climate has changed significantly, with the observed increase in temperature being twice the global average (Notz \& Stroeve 2018; Lewkowicz \& Way 2019).

Warming in the Arctic has accelerated and intensified geomorphological processes that directly affect human safety (IPCC 2014; IPCC 2019). The Arctic Coast Report highlights the role of the coastal zone as an area where serious environmental changes have a direct impact on Arctic communities (Forbes 2011; Strzelecki 2011; Overduin et al. 2014). Contemporary Arctic coastal landscapes have been greatly modified by the following factors: the accelerated degradation of permafrost, the thawing of which threatens existing infrastructure (Wobus et al. 2011; Walker et al. 2015; Doré, Niu \& Brooks 2016; Debortoli et al. 2019; Karjalainen et al. 2019), the increased supply of withdrawing glacier deposits (Strzelecki, Małecki \& Zagórski 2015; Bendixen et al. 2017; Bourriquen et al. 2018), which could lead to the shallowing of harbour basins (e.g. the old Svea settlement coal port on Svalbard), and the extension of the period without sea ice which causes increased exposure to storm waves and accelerated coastal erosion (Jones et al. 2013; Zagórski et al. 2015; Isaev et al. 2019). These intensified destructive activities directly threaten the Arctic coastal communities and hinder the planning of new investments (Andrew 2014). Although the effects of Arctic warming require sustainable planning and management from decision-makers and investors (Wilson \& Piper 2010), this issue is still marginalised in public debate (Jaskólski et al. 2018a).

\section{Objectives, Methods \& Research area}

The aim of this paper was to review and summarise the most important studies on the interaction between humans and the environment in the Arctic coastal zone under the impact of the warming climate and associated geohazards.

The main method to achieve this goal was a widespread literature search, which included the following: scientific articles and books, media reports, popular science books, tourist guides, planning materials, aerial photographs and census databases. The research paper drew on information from over 140 bibliographical items published between 1960-2020, and the following combinations of keywords in particular were used in the literature search: arctic environment, arctic settlements, arctic coast, geohazards, environment changes, anthropogenic impact, human impact, climate change risks, permafrost thaw, permafrost degradation, tundra fire, retrogressive thawslumps, 
arctic tsunami, polar vegetation, arctic culture, sea ice extent, glacier retreat, arctic development, arctic history, arctic pollution, landscape degradation.

In the paper, the author uses the term 'Arctic settlement' instead of, for example, 'Arctic Town' or 'Arctic City'. This is due to the difficulty of transposing onto the Arctic area the European understanding of a city as a creation with a leading service function. When using the term Arctic settlement here, the author is refering to a settlement that has been inhabited all year round for at least the last 10 years. In order to show the spatial relations and leading functions (Figure 1), a criterion of limiting the presented settlement units to a minimum of 100 inhabitants was also applied. For the purposes of Figure 1, 81 settlement units with population ranging from 100 to 71,000 inhabitants were analysed. The leading function was interpreted on the basis of available aerial and satellite photographs and local plans. The shape, function of the buildings, statistical data and available scientific literature were analysed. A detailed table, with a list of all the analysed localities, can be found in the Appendix. To illustrate the complexity of current interactions between man and the environment on the Arctic coast, Figure 2 was created, as this illustrates the general character of the Arctic settlement locations on the Arctic coast and the processes most frequently described in the literature.

The research area, interpreted as the Arctic coastal zone, was limited to a strip of the Arctic coastline (up to $10 \mathrm{~km}$ wide) inhabited by humans all year round, which is influenced by peri- and paraglacial processes as well as landscape-shaping processes related to the activity of the sea (e.g. sea ice, wave impact).

Humans in the Arctic

Human activity in the Arctic over the centuries

From the outset, a clear distinction should be made between the activities of indigenous Arctic peoples and so-called western civilisation. According to various sources, the early presence of indigenous people in the Arctic, dates back one thousand to several thousand years (Rowley 1940; Taylor 1963; Morrison 1989), while western civilization reached the Arctic only in the sixteenth century when exploration of the Arctic was initiated on a wave of great geographical discoveries (McCannon 2012). This research focuses primarily on the activities of western civilisation in the Arctic, regarding it is an intruder, intensive exploiter and the main driver of the negative impact on the environment. To understand today's human presence and settlement structure in the Arctic, it is necessary to trace its activities over the centuries. From the very beginning, human activity in the Arctic has focused on exploration for exploitation (Robinson 1966; McCannon 2012). For a better understanding, a generalised chronology of the conquering of the Arctic is presented below.

The first organised Arctic settlements were base camps and factories [e.g. Smeerenburg and Herschel Island in the 17th and 18th century] and they served the whaling and fur trade industries [ports, fish oil melting plants, storage] (Burn 2017; Stange 2018). Then, at the turn of the 19th century, intensive extraction of natural resources began, including the following: the Klondike Gold rush, which was an important stimulant for the population of the border region of Alaska and Yukon (Berton 2001; Waltham 2007), the formation of mining settlements for the extraction of hard coal in Svalbard [Longyearbyen, Barentsburg, Pyramiden and Brandal City - today's Ny-Ålesund] (Stange 2018), as well as the exploration of Siberia which led to the establishment of industrial cities such as Norilsk [Nickel], Vorkuta [Coal], and Murmansk [Mineral extraction], (Kontorovich 2015). The next stage of human activity in the Arctic was establishing a military presence, initiated during the Second World War. Near Narvik
[Norway], there was a battle for heavy water (Evans 1999). Iceland was preventatively occupied by the United Kingdom (Miller 2003). Svalbard hosted German meteorological stations providing key forecasts for the Atlantic theatre of naval warfare (Stange 2018). The waters of the Arctic ocean, under a U.S. agreement with the U.S.S.R. [Lend-Lease] were used by convoys transporting tanks, vehicles, aircraft, weapons and ammunition to the Arctic ports of the Soviet Union. Subsequently, the Arctic became an area of activity during the so-called Cold War. In Northern Canada, Distant Early Warning Line (DEW Line) radar stations (Lackenbauer \& Farish 2007), military bases and airports were built, e.g. the US Air Base in Kangerlussuaq, Greenland (Dzik 2014). The USSR build the Novaya Zemlya nuclear training ground (Khalturin et al. 2005). After the end of the Cold War, many of these bases were abandoned, but now the Arctic is, once again, becoming an area of increased interest to world powers (Łuszczuk 2015; Bennett 2018). This is evidenced by recent reports on the activation of Arctic bases by the Russian Federation, e.g. on Kotelny Island (Siminski 2013), the construction of nuclear icebreakers by China (Zhen 2018) as well as the recent declaration by the US President of his wish to purchase Greenland (Pengelly 2019). These contemporary reports show that the Arctic is still the focus of attention and show how important it is to deepen the relationship between the human presence and the environment in the Arctic.

Needs and determinants of settlement in the Arctic

Many forms of settlement are present in the Arctic area, ranging from small scientific bases, ephemeral camps associated with the mining industry, to cities numbering several hundred thousand inhabitants such as Murmansk or Norilsk. The largest number of settlement units, as classified under the author's population criterion, are located in Norway (30) and Greenland (23) and the smallest number are in Canada (10) and the USA (5). The largest settlement units are Norway's Troms $\varnothing$ (pop. 71,590) and Russia's Tiksi (pop. 50,063) and the smallest are Greenland's Illorsuit (pop. 101) and Canada's Sachs Harbour (pop. 103). The dominant function of a given urban unit, based on the literature research, spatial distribution and character of the land use \& buildings, was assessed. The vast majority of the settlements surveyed are engaged in a dominant function related to fishery \& hunting (30) and fishery (13). Tourism as the leading was held by a minority of settlements (4).

There are many more smaller settlements and urban units in the Arctic, not directly located in the coastal zone, which provide important support functions for the Arctic community and the industries operating there, which need to be managed.

In many respects, spatial management in the Arctic area is more challenging than in lower latitudes (Kenny 2017). During the planning and management of living space in this area, people have always had conflicts of interest. On one hand, we have the environmental aspects such as extreme weather phenomena, polar night and day periods, vulnerable ecosystems and global climate change. On the other hand there are the anthropogenic aspects, such as settlement development, fishing, mining and, for several decades now, tourism as well. These are conflicting factors which, in a complex interaction, overlap in Arctic conditions, in the same place and at the same time (Fig. 2). These factors permeate and interact with each other over a small area of the coastal zone where human activity is concentrated (Kaltenborn \& Emmelin 1993).

The spatial management of Arctic cities is characterised by a very limited amount of space available for development. Having limited space requires rational and safe planning and construction. Climate change, which has a direct impact on Arctic shores, forces spatial planning to take into account forecast landscape (geomorphological) changes, both in terms of logistics 


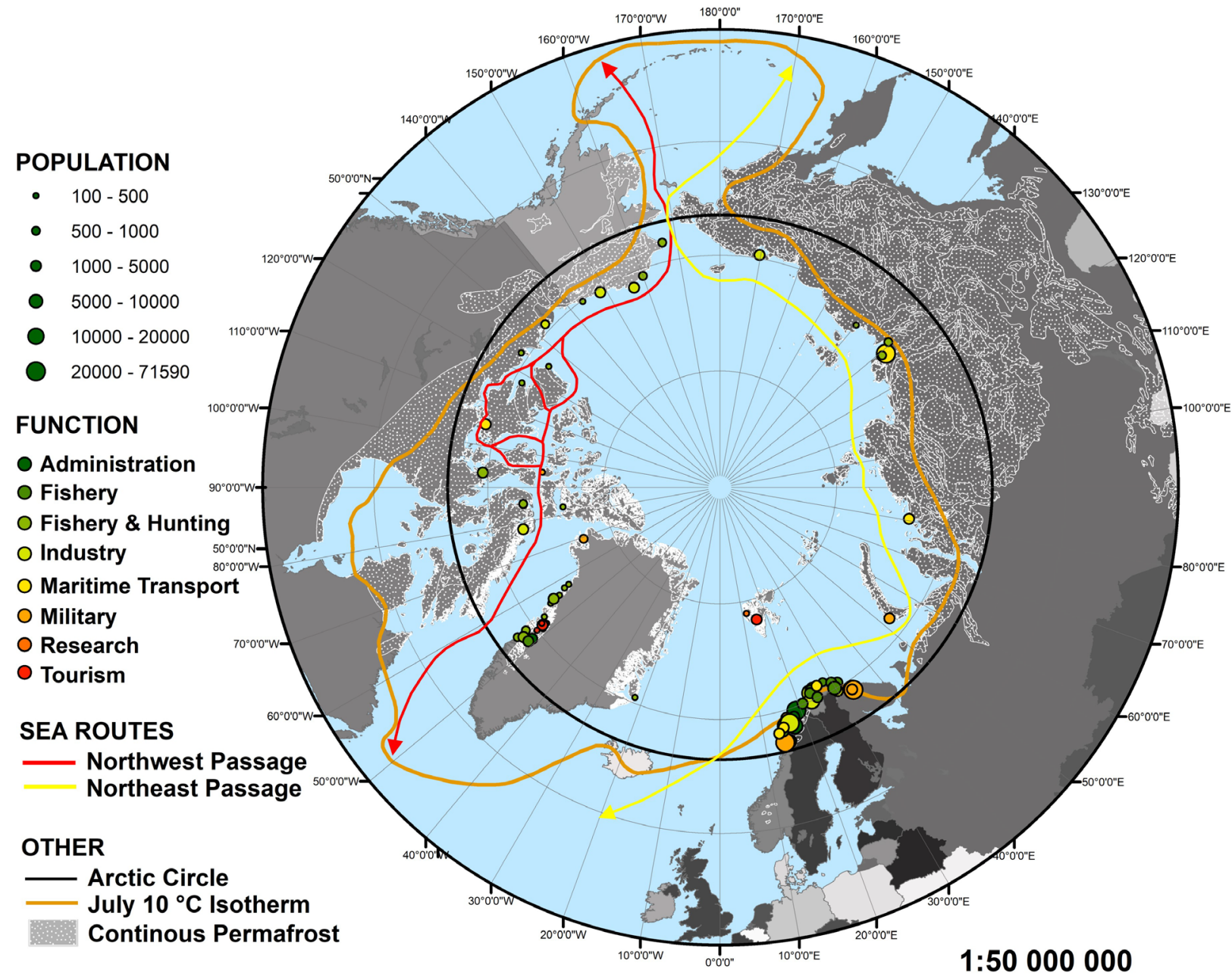

Figure 1. Arctic coastal settlements in geographical context Sources: sea routes are based on Rahman et al. 2014, and thearcticinstitute.org; boundary shape files are from arcgis.com; the July isotherm is based on Kling 2009; permafrost limitation is based on www.nsidc.org and gtnp.arcticportal.org

(e.g. safe road and sea routes) and environmental issues (e.g. location of environmentally-harmful landfills at a safe distance from the sea). Bearing in mind the environmental issues and, in particular, the very fragile ecosystem, it should be stressed that all human activities have a temporary or permanent, substantive or potential impact on the environment. The specificity of the Arctic area is a major challenge for planners.

A key aspect of human presence in extreme Arctic conditions is related to security. This is directly affected by the housing conditions and efficient logistics associated with unobstructed and efficient transport and communication infrastructure (Kenny 2017; Bennett 2018). The high costs of investing in the Arctic are mainly due to the extreme weather conditions; the problem of distance and the durability of infrastructure. Weather variability and the harsh Arctic climate necessitate the use of specialised equipment capable of withstanding such conditions (Ermida 2014). Weather conditions translate directly into the length and efficiency of transport. Distances between settlements and supply chains are another factor that increases operating costs in the Arctic. The supply of food, building materials, fuel and spare parts for distant settlements requires continuity. Despite the dynamic growth of air transport, Arctic settlements are still largely dependent on maritime transport, and air transport remains a more expensive and weather-sensitive alternative.

When establishing the first Arctic settlements, the primary deciding factor was convenient access to the sea; so a secluded bay, free from ice for as long as possible, was primarily looked for (Steinecke 1999). Depending on the time they were to be there, these settlements served as factories e.g. Ilulissat (Greenland), trapper settlements e.g. Wainwright (Alaska), whaler settlements e.g. Herschel Island (Canada), expedition / scientific settlements e.g. Ny-Ålesund (Svalbard), and industrial settlements e.g. Poljarny (Russia). In many cases, the leading functions of the settlements have been subjected to succession, but in the vast majority, the demand for efficient transport routes to serve them has increased. Therefore, it can be concluded that the priority in spatial management of the Arctic area is still related to patency and transport stability, which together guarantee the existential stability of settlements. Especially in the case of settlement units with a predominately industrial function, the issue of transport beyond basic provisioning determines their economic potential. The more we can transport, the more we can profit from the sale of the extracted goods. 


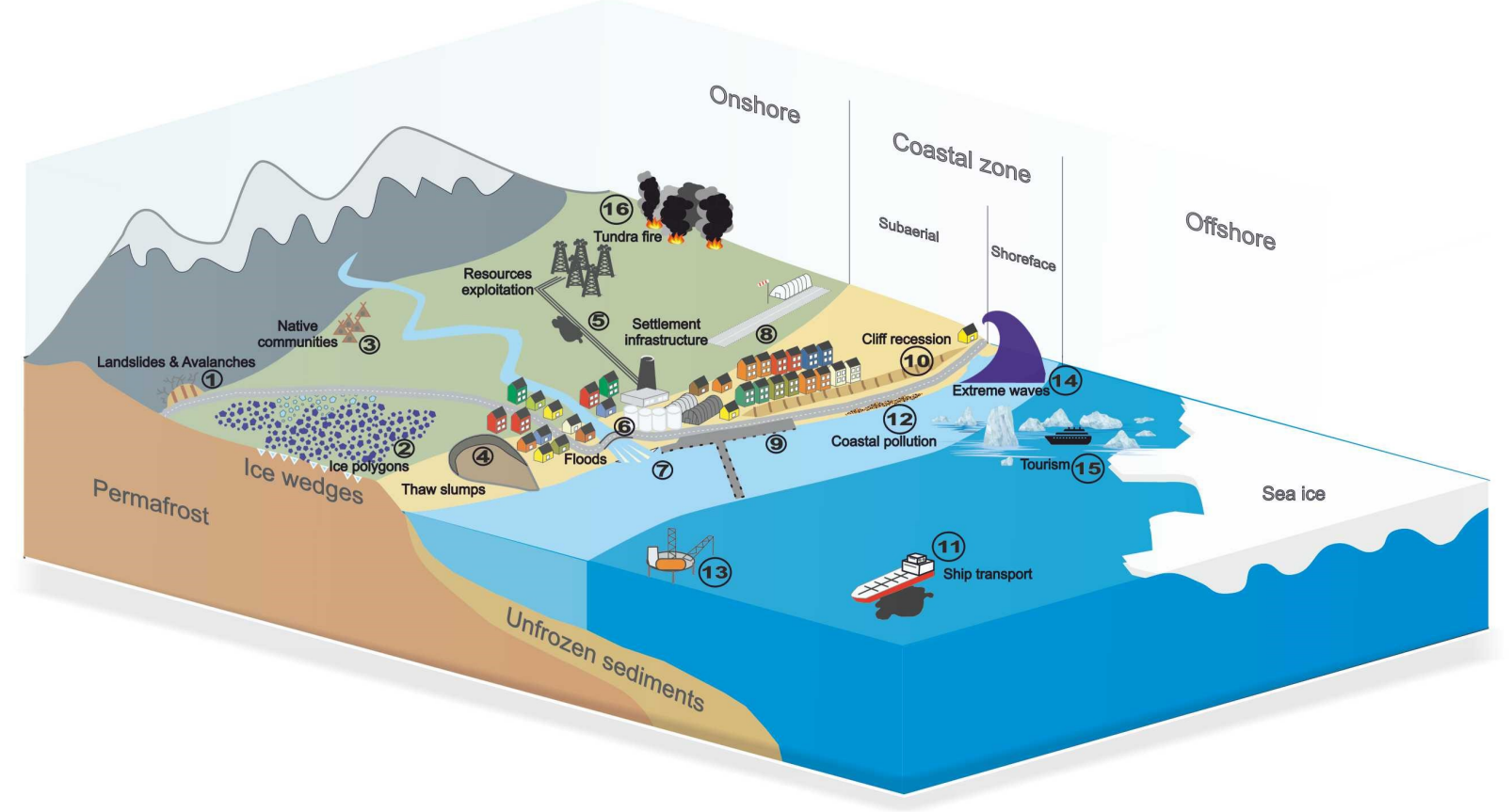

Figure 2. Anthropogenic and environmental interactions affecting the Arctic coast 1.Landslides caused by heavy rainfall (Prno et al. 2011) 2. Destruction of roads caused by disturbance of the permafrost regime (Walker et al. 2015) 3. Indigenous peoples' migration due to reduced hunting areas (Gorkhovich 2014) 4. Thaw slumps and mudflows in response to increased permafrost thaw (Lantuit et al. 2011, Lewkowicz \& Way 2019) 5. Oil and gas pipeline leaks 6. Destructive effects of flooding 7. Harbour basin shallows due to increased sedimentation (Mercier \& Laffly 2005) 8. Destruction of asphalt and concrete surfaces by deepening the active layer of permafrost (McFadden \& Bennett 1999; Jørgensen \& Andreasen 2007) 9. Intensified undercutting \& erosion of the coastline, destruction of port infrastructure (Strzelecki et al. 2017; Jaskólski et al. 2018a); 10. Communication routes and transport infrastructure threatened by mass movements (Prno et al. 2011; Jaskólski et al. 2017) 11. Increasing use of the north-east passage and north-west passage (Ermida 2014; Stephen 2018) 12. Pollution \& littering of the coast (Bergmann et al. 2017; Jaskólski et al. 2018b) 13. Increasing exploitation of natural resources (Ermida 2014; Stephen 2018) 14. Extreme waves destroying infrastructure (Dahl-Jensen et al. 2004; Buchwat et al. 2015) 15. Increased tourism negatively affecting the Arctic environment (Dawson, Johnston \& Stewart 2017) 16. Tundra fires (Jones et al. 2015)

Despite the existing technologies enabling the construction of even multi-storey buildings on permafrost, the planning and implementation of linear facilities is still very expensive and energy-intensive from a technological point of view. The operation of ergonomic and efficient media systems (electricity, heating, sewerage, water supply) as well as planning and implementation of road construction, require special attention and significant financial investment. For example, when locating a road, the distances from active surface watercourses and hills with steep slopes play an important role. The location and construction of roads, in particular those made of concrete and asphalt, requires thorough knowledge of the lithology to minimise subsidence and cracks in the road structure. Preparing the ground for buildings is often requires the use of heavy equipment and blasting works that significantly increase investment costs. Permafrost and its dynamics, which occur in most of the Arctic (Fig. 1), contribute to the destruction of buildings, roads, runways and elements of Arctic cultural heritage. If technically possible, permafrost should be removed to as deep a depth as possible and the remainder should be cooled (e.g. using thermosyphons). The artificiallycreated surface requires the use of appropriate colours and materials that will reflect the sun's rays, without causing excessive heating and thawing of the permafrost (McFadden \& Bennett 1991). The importance of using the right technology in the era of climate change can be illustrated by the example of research conducted at the airport in Greenland Kangerlussuaq (Jørgensen \& Andreasen 2007). This is the largest airport in Greenland with both military and civilian functions. The airport runways are partly covered with asphalt. On those surfaces where asphalt was used, thawing of permafrost occurs deeper than in areas without the dark asphalt layer absorbing solar energy. In some areas of the airport, this contributes to the accumulation of meltwater under the surface. In the warm period, when the permafrost is thawing, sediment saturated with water destabilises the ground-bearing capacity and the structure of the airport apron. This is very important, given the high loads associated with aircraft takeoff and landing (Jørgensen \& Andreasen 2007). In this context, attention should be paid to the need to drain communication routes efficiently. Water accumulated under the road surface can quickly change the thermal regime of the base soils, increasing the risk of damage to the road structure or the runway. The active layer of permafrost during the winter is frozen, but at the end of summer, its thickness can increase to about $2.5 \mathrm{~m}$ with a rising tendency in recent years (Hjort et al. 2018; Kasprzak et al. 2020). The richer the permafrost layer, the thicker the layer supporting the road structure, or the longer the pillar supporting the building needs to be. This unfortunately significantly increases the costs of these investments in Arctic conditions (Schraeder, Riddle \& Slater 1996). The above conditions of spatial planning and investing in the Arctic show how complex this issue is. 
Climate change-induced challenges and threats to Arctic settlements

Temperature rise is a major factor in changes in the Arctic landscape (IPCC 2014; IPCC 2019). Warming of Arctic areas has triggered a number of cause and effect relationships that interact (Tab. 1). Due to climate changes observed in the Arctic area, extreme phenomena such as strong storms and gales are increasingly frequent (Screen et al. 2011; Vermaire et al. 2013). For example, in summer 2007, $173.5 \mathrm{~mm}$ of rain fell in the Kugluktuk settlement in Nanavut, Canada, during two days of heavy rainfall. The extreme scale of this event is evidenced by average annual rainfall of approximately $250 \mathrm{~mm}$ in the area. As a result of the storm, many buildings were washed away, culverts overflowed, roads were destroyed, and many families were left homeless (Prno et al. 2011) (Figure 2;6). Temperature anomalies have become the norm; summer 2019 was the warmest Arctic summer ever recorded (Staalesen 2019). Changes in temperature distribution over the year cause, for example, periods of thaw in winter, resulting in increased risk of avalanches, that were previously sporadic. On 19th December 2015, an avalanche hit the centre of Longyearbyen, Svalbard, killing one person, injuring nine more and destroying several houses (Agence France-Presse 2015). In February 2017, Longyearbyen again experienced an avalanche which, this time, destroyed two residential buildings (Næss 2017). The increase in average temperatures and higher precipitation directly affect the stability of the slopes (Fig. 2;1,4,10). The mostly barren slopes, which are covered with non-consolidated material due to para and periglacial processes, and with permafrost, are susceptible to the intensification of mass movements such as thaw slumps, landslides, avalanches, mudflows and solifluction. This poses a significant threat to the settlement infrastructure located near the slope. The direct consequences of mass movements can destroy buildings and roads (Jaskólski et al. 2017), burying people in the landslide area, or cut off supply lines or escape routes (Fig. 3 ; k)

Examples of the indirect effects on humans of mass movement activities include the incident of mudflows near the Deering settlement in north-west Alaska. In addition to morphological changes, this run-off has also led to strong ecosystem changes, such as reduced access to drinking water and reduced fish populations, forcing the indigenous population to search for new hunting grounds (Gorokhovich, Leiserowitz \& Dugan 2014) (Fig. 2;3). One extreme consequence of landslides is tsunami. The largest wave so far was recorded in 1958, in the Bay of Lituya in Alaska, and was approximately $500 \mathrm{~m}$ high (Miller 1960; Weiss, Fritz \& Wünnemann 2009) (Fig. 2;14). Greenland, in particular, has experienced significant tsunami impacts over the last two decades. In 2000, a tsunami from Mount Paatuut destroyed the Qullissat settlement, the impact of which could be seen up to 150 $\mathrm{km}$ from the landslide (Buchwał et al. 2015; Dahl-Jensen et al. 2004). The most tragic date associated with a tsunami landslide is 17th June 2017, when a landslide in the Karrat fjord caused a tsunami wave that destroyed the Nuugaatsiaq settlement, killing 4 people and injuring a further 9 (Figure 3; i). The wave destroyed 94 buildings and forced 39 people to evacuate and leave their homes for good (Strzelecki \& Jaskólski 2020).

The increased rate of permafrost thaw in particular contributes to the destabilisation of slopes, but so also do anthropogenic structures such as flood banks and artificial coasts. The increase in the rate of permafrost thaw is a problem in itself; the increase of the so-called active layer, which thaws in summer and freezes in winter, destabilises the ground bearing capacity and thus everything built on it (Fig. 2;2,5). High buildings, oil and gas pipelines, as well as roads and runways, are particularly affected (Fig. 3; a,c,I). Increased permafrost thawing is at present the greatest threat to Arctic infrastructure (Lantuit et al. 2011; Shiklomanov et al. 2017; Jaskólski et al. 2018a; Streletskiy et al. 2019; Anisimov \& Orttung 2019; Teufel \& Sushama 2019). This is shown by recent press reports and field observations, e.g. in May 2017, The Guardian reported that part of the Global Seed Vault on Svalbard was flooded as a result of permafrost thawing (Carrington 2017).

The effects of permafrost thawing are felt most severely by the indigenous inhabitants of the Arctic settlements, who are often forced to leave areas inhabited for centuries by their ancestors. The thawing permafrost changes the whole ecosystem, hindering access to primary hunting areas, disrupting the water regime, and preventing the use of traditional ice houses in which food supplies have been stored for generations (Bronen 2010; Bronen \& Chapin 2013; Cochran et al. 2013). A good example is the Newtok settlement in Alaska, where the thawing permafrost and erosion washed away the landfill site and significantly endangered the construction of fuel tanks. The collapsing infrastructure and risk of flooding forced the regional authorities to decide to evacuate the entire population of 350 people (Welch 2019) (Fig. 2;3,8). It should also be added that thawing permafrost is accompanied by the release of greenhouse gases stored in it, which, when released, cause feedback into further Arctic warming (Fig. 3; g) (Schuur et al. 2009). The acceleration of permafrost thaw is also influenced by the increasing frequency of tundra fires. (Higuera et al. 2011). During one of the largest fires in northern Alaska in 2007, the fire consumed $\sim 1,000 \mathrm{~km}^{2}$ of land (Jones et al. 2015) (Fig. 2;16). Permafrost thaw has a strong impact on coastline recession. In areas characterised by a high proportion of ice in the sediments forming the coast, thaw slumps are formed (Lantz \& Kokelj 2008; Balser et al. 2014). There is also an intensified process of thermal abrasion which in extreme cases causes recession of the coastline of up to $5 \mathrm{~m} /$ year (Radosavljević et al. 2016; Obu et al. 2017) (Fig. 2;9).

The increase in average temperature in the Arctic directly affects the reduction of sea ice extent, which has, so far, protected coastal settlements from the development of waves. Open water without sea ice cover, especially during the storm season [Autumn, Spring] causes increased erosion of Arctic coasts (Overeem et al. 2011; Graham et al. 2019). Coastline that is undercut by waves is receding right across the Arctic, and this process threatens all coastal infrastructure, such as scientific facilities (Fig. 3;j), port infrastructure (Fig. 3;e,d), warehouses, fuel depots, heritage sites etc. (Zagórski et al. 2015; Strzelecki et al. 2017; Strzelecki et al. 2017; Jaskólski et al. 2018a; Nicu et al. 2020; Zagórski et al. 2020). The receding coastline is not just a financial risk; a significant part of the cultural heritage of the indigenous Arctic population is now also at risk of irreversible loss (Figure 3;h) (Radosavljević et al. 2016; Irrgang et al. 2019). Apart from coastal erosion, additional threats to cultural heritage in the Arctic include: general mechanical weathering, wind wear and tear, sand drift, flooding and human activity (Holmgaard et al. 2019). These days, the human impact on cultural heritage is a topic of increasing relevance in the Arctic due to the expanding tourism industry (Bystrowska, Wigger \& Liggett 2017; Holmgaard et al. 2019).

The erosion threat to settlement infrastructure doesn't only come from the sea. Arctic warming accelerates glacier melting and withdrawal, which makes the Arctic's water courses carry more meltwater, particularly in the summer season. Settlements located in the vicinity of glacial rivers are exposed to increased riverbed erosion and rapid flooding (Fig. 2;7) (Jaskólski et al. 2018a). At the same time, disappearing glaciers and more meltwater are accompanied by an increase in the accumulation material carried by the river. This material builds up in estuaries and shallows port basins, thus reducing the possibilities for sea transport and threatening vessels directly (Fig. 2;7) (Eyles 1988; Syvitski 1989; Bogen \& Bønsnes 2003; Mercier \& Laffly 2005). It is worth noting that, while the melting of glaciers brings a lot of water to the riverside, the glaciers themselves are often a strategic reservoir 
MISCELLANEA GEOGRAPHICA - REGIONAL STUDIES ON DEVELOPMENT

Vol. $25 \cdot$ No. $2 \cdot 2021 \cdot$ pp. 127-143 • ISSN: 2084-6118 • DOI: 10.2478/mgrsd-2020-0036

Table 1. Review of cause and effect relationships of environmental processes related to climate change

\begin{tabular}{|c|c|c|c|c|c|}
\hline Process & $\begin{array}{c}\text { Area of } \\
\text { occurrence }\end{array}$ & Triggering factor & Effect & Threat & Literature Example \\
\hline $\begin{array}{l}\text { Landslides / } \\
\text { Thaw slumps }\end{array}$ & Slope & $\begin{array}{l}\text { Increased volume of } \\
\text { rainfall, storms and } \\
\text { thawing permafrost } \\
\text { exceeds the retention } \\
\text { possibilities of slope } \\
\text { sediments that are } \\
\text { mostly weathered } \\
\text { and not covered with } \\
\text { vegetation. }\end{array}$ & Slide of rock material & $\begin{array}{l}\text { A direct threat to } \\
\text { road and settlement } \\
\text { infrastructure } \\
\text { The triggering of } \\
\text { tsunami waves }\end{array}$ & $\begin{array}{c}\text { Prno et al., 2011; } \\
\text { Harbitz et al., 2014; } \\
\text { Buchwał et al., 2015; } \\
\text { Higman et al., 2018; } \\
\text { Lewkowicz \& Way 2019 }\end{array}$ \\
\hline Avalanches & Slope & $\begin{array}{l}\text { Increase in average } \\
\text { temperature, change in } \\
\text { temperature distribution } \\
\text { over time. The } \\
\text { appearance of a thaw } \\
\text { in spring }\end{array}$ & Slide of snow masses & $\begin{array}{l}\text { An immediate threat } \\
\text { to road and settlement } \\
\text { infrastructure and } \\
\text { human life }\end{array}$ & $\begin{array}{c}\text { Stoffel et al., 2006; } \\
\text { Shnyparkov et al., 2012; } \\
\text { Eckerstorfer \& } \\
\text { Christiansen 2012; } \\
\text { Eckerstorfer et al., } 2014\end{array}$ \\
\hline $\begin{array}{l}\text { Permafrost } \\
\text { thaw }\end{array}$ & Anywhere & $\begin{array}{l}\text { Increase in average } \\
\text { temperature }\end{array}$ & $\begin{array}{l}\text { Increasing the thickness } \\
\text { of the active layer, } \\
\text { methane and carbon } \\
\text { dioxide release, greater } \\
\text { water supply, mudflows }\end{array}$ & $\begin{array}{l}\text { Destruction of the } \\
\text { surface of roads and } \\
\text { airfields. } \\
\text { The collapse of } \\
\text { load-bearing pillars, } \\
\text { disruption of the } \\
\text { construction of gas and } \\
\text { oil pipelines, buildings }\end{array}$ & 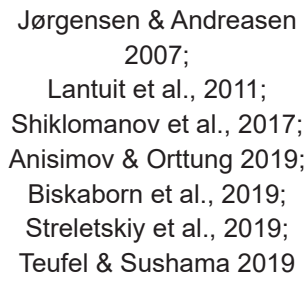 \\
\hline Erosion & $\begin{array}{l}\text { Coastal zone, } \\
\text { river valleys }\end{array}$ & $\begin{array}{l}\text { The disappearance of } \\
\text { sea ice enabling the } \\
\text { development of waves, } \\
\text { an increase in the } \\
\text { amount of river water } \\
\text { through intensified } \\
\text { melting of glaciers and } \\
\text { frequent and more } \\
\text { intensive rainfall }\end{array}$ & $\begin{array}{l}\text { Increased shore erosion } \\
\text { from waves. } \\
\text { Increased erosion in } \\
\text { a river valley through } \\
\text { increased flow in rivers. }\end{array}$ & $\begin{array}{l}\text { Undercutting and } \\
\text { destruction of banks, } \\
\text { reinforcements and } \\
\text { coastal buildings. } \\
\text { Increase in pressure on } \\
\text { bridge and flyover spans }\end{array}$ & $\begin{array}{l}\text { Wobus et al., 2011; } \\
\text { Barnhart et al., 2014; } \\
\text { Zagórski et al., 2015; } \\
\text { Fritz et al., 2017; } \\
\text { Anonymous et al., 2018; } \\
\text { Irrgang et al., 2019; } \\
\text { Nicu et al., 2020 } \\
\text { Zagórski et al., 2020; }\end{array}$ \\
\hline Accumulation & $\begin{array}{l}\text { Coastal zone, } \\
\text { delta }\end{array}$ & $\begin{array}{l}\text { Intensified melting of } \\
\text { glaciers and erosion in } \\
\text { riverbeds }\end{array}$ & $\begin{array}{l}\text { Increased supply of } \\
\text { accumulation material, } \\
\text { increase in shallows } \\
\text { (particularly dangerous } \\
\text { in harbour basins and } \\
\text { accesses) }\end{array}$ & $\begin{array}{c}\text { Danger to maritime } \\
\text { navigation, limitation of } \\
\text { Arctic port capacity }\end{array}$ & $\begin{array}{l}\text { Mercier \& Laffly 2005; } \\
\text { Zajączkowski et al., 2008; } \\
\text { Sessford et al., 2015; } \\
\text { Strzelecki et al., 2015; } \\
\text { Bourriquen et al., 2018; }\end{array}$ \\
\hline Floods & $\begin{array}{l}\text { Coastal zone, } \\
\text { river valleys }\end{array}$ & $\begin{array}{l}\text { Intensified melting } \\
\text { of glaciers, weather } \\
\text { anomalies, a general } \\
\text { increase in precipitation } \\
\text { in the Arctic }\end{array}$ & $\begin{array}{l}\text { Erosion of river beds, } \\
\text { flood plains, flooding of } \\
\text { river valleys }\end{array}$ & $\begin{array}{l}\text { An immediate threat } \\
\text { to road and settlement } \\
\text { infrastructure and } \\
\text { human life }\end{array}$ & $\begin{array}{c}\text { Peterson et al., 2002; } \\
\text { Kane et al., 2003; } \\
\text { Rachlewicz, 2009; } \\
\text { Prno et al., 2011; } \\
\text { Dahlke et al., 2012; } \\
\text { Radosavljević et al., 2016 }\end{array}$ \\
\hline Tundra fires & Anywhere & $\begin{array}{l}\text { Average temperature } \\
\text { rise, Tundra drying, } \\
\text { Anthropogenic pressure }\end{array}$ & $\begin{array}{l}\text { Reduction of biomass, } \\
\text { the disappearance of } \\
\text { ecosystems, increase of } \\
\text { greenhouse gas supply } \\
\text { to the atmosphere }\end{array}$ & $\begin{array}{l}\text { An immediate threat } \\
\text { to road and settlement } \\
\text { infrastructure and } \\
\text { human life }\end{array}$ & $\begin{array}{l}\text { Higuera et al., 2011; } \\
\text { Jones et al., } 2015\end{array}$ \\
\hline $\begin{array}{l}\text { Migration of } \\
\text { species }\end{array}$ & Anywhere & $\begin{array}{l}\text { Average temperature } \\
\text { rise, Tundra drying, } \\
\text { Anthropogenic pressure }\end{array}$ & $\begin{array}{l}\text { Migration of species, loss } \\
\text { of ecosystems }\end{array}$ & $\begin{array}{c}\text { Migration of indigenous } \\
\text { peoples engaged } \\
\text { in reindeer herding, } \\
\text { hunting and fishing }\end{array}$ & $\begin{array}{l}\text { Walker \& Everett 1987; } \\
\text { Hitch \& Leberg., 2007; } \\
\text { Gorokhovich et al., 2014; } \\
\text { Walker et al., 2015; } \\
\text { Maliniemi et al., 2018 }\end{array}$ \\
\hline
\end{tabular}

Source: own elaboration 

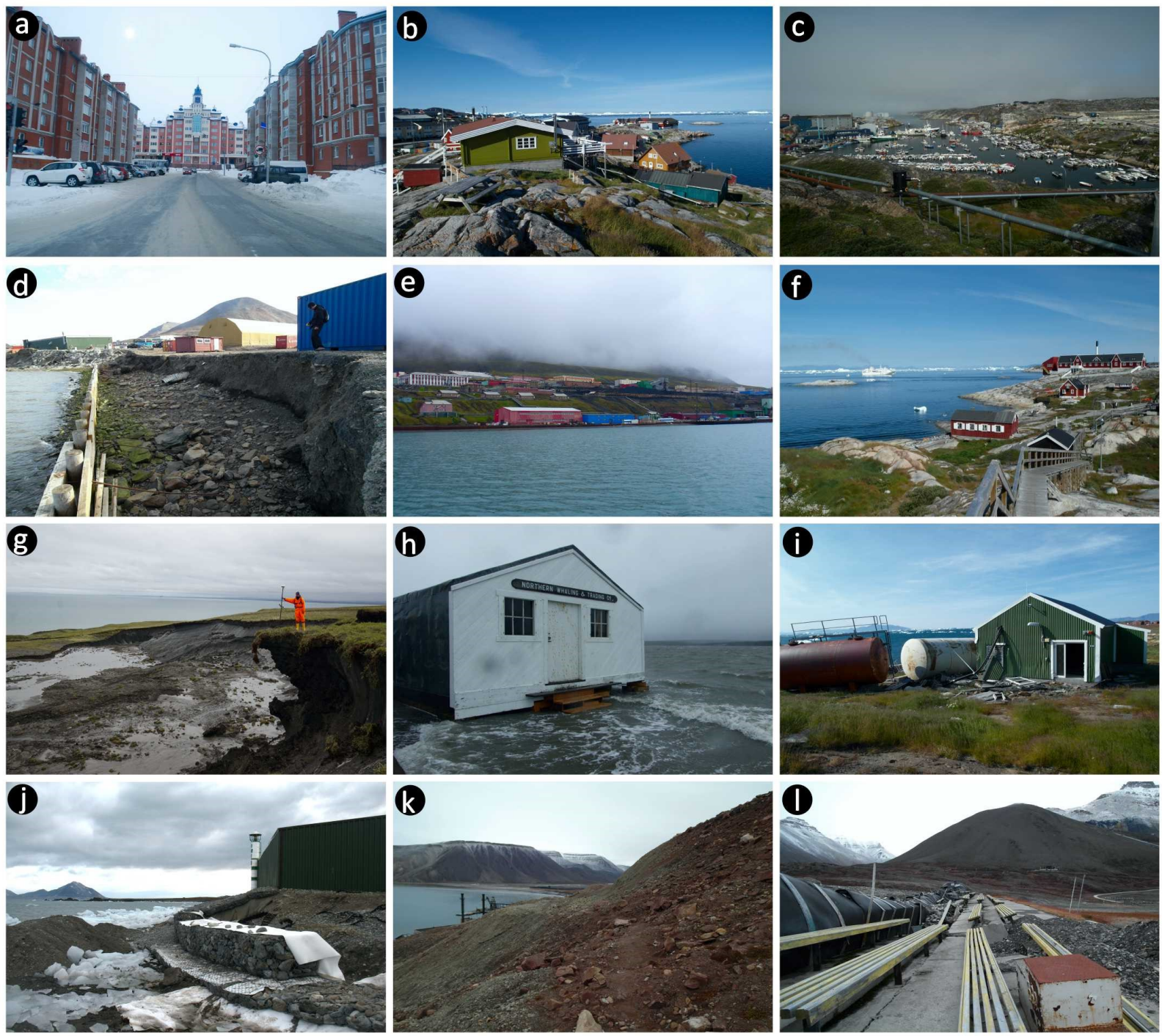

Figure 3. Settlements and their challenges in different parts of the Arctic

a) Salekhard, Russia: in the future, these multi-storey buildings will be threatened by increasing permafrost thaw; $b$ ) Ilulissat, Greenland: a noticeable lack of convenient investment locations; c) Port in Ilulissat, Greenland: visible water and sewage pipes, fish processing plant and warehouses in the distance d) Longyearbyen, Svalbard: erosion threatening the warehouses; e) Barentsburg, Svalbard: a characteristic distribution of Arctic buildings located on the coast; f) Disko Bay, Greenland: visible exhaust emissions from a cruise ship; g) Herschel Island, Canada: the thawing permafrost cliffs are causing coastal retreat; $h$ ) Qikiqtaruk Territorial Park, Canada: historic buildings flooded by the sea are UNESCO candidates; i) Nuugaatsiaq, Greenland: buildings destroyed by tsunami waves; j) Polish Polar Station Hornsund, Svalbard: erosion threatening the station infrastructure forces annual renovation of coastal protection elements; k) Pyramiden, Svalbard: a landslide cut off the road; I) Pyramiden, Svalbard: thawing permafrost caused the collapse of the shooting range and the stands;

Source: photos (a-g, i-k) taken by Marek Jaskólski; photo (h) taken by Team Shrub, University of Edinburgh

of drinking water for the local communities. The recession of glaciers is at once a distancing and reduction of drinking water reserves. Glacier calving itself poses a threat for marine traffic and infrastructure. Here, two types of risk scenario can be distinguished; the direct risk of a tsunami caused by the mass of ice breaking away from the face of the glacier and secondly, by the rolling of a drifting iceberg (Heller et al. 2019). High temperatures events, which are increasingly being observed, can also lead to flooding due to the large amount of glacier melting.

The description above of the processes caused and intensified by Arctic warming, clearly shows the need for multifaceted and sustainable planning of future settlement infrastructure. At the same time, existing buildings should be assessed in the context of the risk of the occurrence of the above-mentioned processes and adapted to the new conditions.

\section{Prospects for people \& risks for the environment} Extraction industry

The warming of the Arctic is accompanied not only by threats to human beings but also by significant economic opportunities (Andrew 2014). Sea ice disappearance and higher average annual temperatures facilitate access to Arctic resources. Fossil fuels present beyond the North Arctic Circle are estimated at 20$30 \%$ of the world's resources (Auswärtiges Amt 2013). The Arctic 
has rich deposits of copper, nickel, zinc and rare earth metals, e.g. molybdenum. Currently, the largest oil and gas fields in the Arctic are Prudhoe Bay, along with part of the Beaufort and Chukchi Seas and Tazovskoye including the Yamal Penisula and Kara Sea (Houseknecht \& Kenneth 2005) (Fig. 2;13). The projected increase in Arctic extraction activity poses a significant threat to the environment (Stephen 2018). Field operations and associated infrastructure such as drilling rigs, roads, oil and gas pipelines are changing the Arctic landscape and forcing indigenous peoples and flora and fauna to migrate (Maki 1992; Stephen 2018).

Line infrastructure elements routed through permafrost areas disturb the natural water regime (Walker et al. 2015). Car traffic leads to the so-called "road dust" effect, i.e. road dust agitated by moving vehicles that dries out the area and covers vegetation, thus negatively affecting local ecosystems (Walker \& Everett 1987; Walker et al. 2015). Local gas and oil transport is mostly via oil and gas pipelines, which are seriously at risk of springing leaks due to thawing permafrost (Singh 2013). International transport of extracted resources and supplies for Arctic settlements takes place mainly by sea.

\section{Activity on the sea}

The warming of the Arctic which accompanies the disappearance of sea ice heralds an intensification of maritime traffic in the Arctic (Khon et al. 2010). It is estimated that in the near future, traffic on the so-called northern routes, north-eastern and north-western passages (Fig. 1), i.e. the alternative much shorter and more independent sea routes connecting the Atlantic Ocean with the Pacific will increase significantly (Fig. 1, Fig. 2;11) (Bennett 2014). For comparison, a sea trip from Dalian (China) to Rotterdam (Netherlands) takes about 48 days and requires an expensive crossing of the Suez canal. The same route taken via the northern seas takes just 35 days (Rahman, Saharuddin \& Rasdi 2014). The intensified use of northern sea routes will be connected with the need for infrastructure investments, e.g. expansion of ports and construction of new ports serving future sea traffic (Nyman et al. 2019). The Arctic is also affected by the dynamic development of tourism, with the number of tourists increasing year by year (Fig. 2;15) (Dawson, Johnston \& Stewart 2017). In particular, cruise tourism is popular, which unfortunately has a strong negative impact on the environment due to high emission of exhaust fumes and discharge of sewage and ballast water (Fig. 3;f) (Carić \& Mackelworth 2014; Bystrowska, Wigger \& Liggett 2017). The last decade has seen a significant increase in the pollution of Arctic beaches from municipal waste. This waste, mostly plastic, covers not only the coastlines of inhabited areas but also protected areas, including national parks (Fig. 2;12) (Bergmann et al. 2017; Jaskólski et al. 2018b). The pollution of the Arctic is not only a threat to its flora and fauna but also to the indigenous people who still rely mostly on traditional food supplies (Duhaime et al. 2004). The negative environmental impact of the intensification of traffic in Arctic waters should be worrying. The waters of the Arctic basin are important fishing grounds and it is estimated that currently about $50 \%$ of the fish caught in the Arctic is consumed in the European Union (Auswärtiges Amt 2013; BMBF 2015). Intensified fishing and the expansion of gas and oil exploitation areas have led to biological imbalances in many fishing grounds. This is particularly true for Arctic areas which, due to their abundance of krill, provide food for many fish species. According to the International Whaling Commission (IWC), the noise associated with the increasing exploitation of oil and gas in Arctic waters threatens many cetacean species, including the almost extinct grey whale. At the same time, the greatest threat remains the contamination of water with oil. There are no technologies available to control oil spills quickly in the harsh Arctic conditions (WWF 2012) and in the perspective of increased use of northern maritime routes, the likelihood of spills of oil and other pollutants is also growing.

The future of spatial development of Arctic settlement

The following content presents a general description of an already visible trend in Arctic development. This is based on general economic principles and takes into account the process of globalisation; thus the processes could be taken as a generalised description applicable to the whole Arctic coast. We know that an increase in human activity in the Arctic is expected in the near future. This increase will be characterised by the need to expand existing Arctic settlements (Fig. 3; b). For example, the Nuuk administration (Greenland) forecasts that the population will almost double in the coming decade (McGwin 2017). The development of major settlements is accompanied by an upward trend towards urbanisation and centralisation throughout the Arctic area. This trend is mainly determined by economic factors (Heleniak 2015). While the mining industry is tied to the location of raw materials, tourism and its related services are concentrated in larger settlements with efficient transport infrastructure such as international airports and ports. The location of fish processing plants, a important branch of the Arctic economy, is also concentrated in larger settlements. This is due to the need for processing, storage and further exports of catches, which requires technical infrastructure such as convenient access for ships, strengthened quays, cranes and cold storage (Fig. $3 ; \mathrm{C}$ ). The logical consequence of this is greater availability of work in larger settlements. The urge to live in a larger settlement also results from better access to education, consumer goods, entertainment and health care. First of all, the concentration of population in larger settlement units is cheaper. This can be illustrated by the example of the health service in Greenland, where each settlement has a nursing office and a person trained to perform more or less complicated procedures. However, a qualified doctor visits these places occasionally and it is only a doctor who can qualify a patient for possible further specialist treatment. It should be remembered that both the doctor and the patient must be transported, usually by air, which generates high costs. It is cheaper and more efficient to build and maintain one hospital with a wide range of specialisations, thus minimising the need for transportation of doctors and patients. Therefore, the future will bring greater, but more concentrated, human activity in the Arctic.

\section{Conclusions}

The perspective of an increase in human activity in the Arctic generates the need to adapt to the environmental changes, that are taking place and which threaten people. Thus, humans, as users of the Arctic, are simultaneously the main threat to its environment and first on the receiving end of the negative effects. In order to mitigate the results of unsustainable exploitation in endangered areas and to avoid similar threats in other areas, a mechanism should be provided to ensure rational planning of human activity there. Unlike the Antarctic, the Arctic does not have a common legal document defining the principles of human functioning and protection of its environment. Climate change and the steady increase in a human presence in the Arctic make it clear that there is a need to develop a common strategy for the sustainable development of the Arctic; a strategy that will take into account increasing environmental changes. Unfortunately, a major obstacle to developing a common strategy for human activity in the Arctic is closely related to conflict of interests, see Table 2. The Arctic, unlike the Antarctic, is partially populated by indigenous communities. It has been, and is currently used for economic and military purposes. These factors limit the chances of peaceful, sustainable development by all interested parties. 
Table 2. The conflict of interest on chosen generalized representative examples

\begin{tabular}{|c|c|c|c|c|}
\hline Local population & Global population & Government & Business & Environment \\
\hline $\begin{array}{l}\text { Wants to benefit from } \\
\text { tourism, industry, northern } \\
\text { sea routes, modern } \\
\text { technologies and services }\end{array}$ & $\begin{array}{l}\text { Wants to visit the Arctic } \\
\text { area, have access to } \\
\text { cheaper raw materials } \\
\text { and goods }\end{array}$ & $\begin{array}{l}\text { Wants to benefit from } \\
\text { tourism, industry, } \\
\text { northern sea routes, } \\
\text { modern technologies } \\
\text { and services }\end{array}$ & $\begin{array}{l}\text { Wants to benefit } \\
\text { from tourism, } \\
\text { industry, northern } \\
\text { sea routes, modern } \\
\text { technologies and } \\
\text { services }\end{array}$ & $\begin{array}{c}\text { Increased tourism \& } \\
\text { industry adds to negative } \\
\text { impact on the environment, } \\
\text { tundra trampling, pollution, } \\
\text { increased sea traffic, air } \\
\text { traffic, etc. }\end{array}$ \\
\hline \multicolumn{4}{|c|}{ but } & and \\
\hline $\begin{array}{l}\text { Wants climate security and } \\
\text { the reduction of processes } \\
\text { that have a negative impact } \\
\text { on tourism and their food } \\
\text { security: } \\
\text { - disappearing hunting } \\
\text { areas } \\
\text { - disappearing glaciers } \\
\text { - contamination }\end{array}$ & $\begin{array}{l}\text { Wants climate security. } \\
\qquad \begin{array}{l}\text { Wants: } \\
\text { - to hunt } \\
\text { - to see glaciers } \\
\text { - to see a clean, } \\
\text { unspoiled landscape } \\
\text { - to have a clear } \\
\text { climate conscience }\end{array}\end{array}$ & $\begin{array}{l}\text { Has to introduce limits } \\
\text { e.g. in the number of } \\
\text { tourists and the areas } \\
\text { made available to } \\
\text { them }\end{array}$ & $\begin{array}{l}\text { Wishes to abolish } \\
\text { restrictions e.g. } \\
\text { on the number } \\
\text { of tourists and } \\
\text { the areas made } \\
\text { available to them }\end{array}$ & $\begin{array}{l}\text { Setting limits on marine } \\
\text { traffic or reducing the number } \\
\text { of tourists and the areas } \\
\text { made available to them will } \\
\text { allow the environment to } \\
\text { regenerate in a better way }\end{array}$ \\
\hline
\end{tabular}

Source: own elaboration

It should be emphasised that, while conflicts of interest and their underlying motives concern different social groups and parties, the environment also plays a passive role in this. Nevertheless, the effects of decisions by individual parties and their motives directly affect the environment. The relationship can be clearly defined as an environmental feedback loop - the more human activity in the sensitive Arctic environment, the greater the environmental stress, the greater the environmental stress, the greater the cost to human activity in the Arctic. In conclusion, mankind must understand that only sustainable development in the Arctic will be profitable, even if one of the parties to the conflict of interest will miss out.

Recent publications and reports on climate change reveal a significant increase in the role of spatial planning as a tool for minimising the effects of climate change (Susskind et al. 2015). Unfortunately, the issue of spatial planning is marginalised in the available Arctic sustainable development strategies. This is even more puzzling when we realise that climate change in the Arctic is much more pronounced than at lower latitudes, and that poor planning has a direct impact on human activity and the environment. The need to plan human activities in the Arctic is evident at various levels. Weather-sensitive planning is critical. Delays in equipment delivery generate high costs. The safety of far flung, isolated settlements is a particularly important aspect. The entire settlement infrastructure, the social, industrial and scientific facilities, require complex emergency plans. In order to prevent and cope with emergencies such as natural disasters, tsunamis, floods, epidemics or man-made disasters (e.g. oil spills, marine accidents, etc.), the requirement to have fast and reliable transport and communication channels should be a priority for governance in the Arctic region.

The fight against climate change should start locally, precisely through sustainable planning, in particular, in spatial planning. The urbanisation and centralisation of human activities in the Arctic disturb the indigenous and historical distribution of the population and pose a threat to the continuity of indigenous peoples' traditions, but are more rational in terms of environmental protection. The cumulative, but concentrated, negative impact on the environment are easier to control than smaller, more diffuse, negative impacts. Concentrating human activity in larger settlements will facilitate the reduction of the negative impact on the environment. It is much more profitable to invest in e.g. sewage treatment plants, filters, hydroelectric power plants, etc. in larger settlements. Nevertheless, larger settlements will have to cope with a greater need for provisioning, drinking water, energy, waste disposal and, above all, investment zones. The spatial development of Arctic population centres is limited in particular by the space suitable for development. Investment zones are heavily restricted by morphology and land conditions. The creation of new investment zones through the construction of a waterfront, building in a delta or in the vicinity of slopes, creates a significant threat to development in the context of existing environmental processes. Sustainable, multifaceted spatial planning should satisfy the above requirements.

We already know the current conditions in the Arctic and the prospects for the coming decades, but cities are not built for decades; they should be built for centuries. It should be taken into account that, in the next hundred years, with the current rate of warming continuing, the temperature in the Arctic may rise by as much as $4{ }^{\circ} \mathrm{C}$ (Lenssen et al. 2019; GISTEMP Team 2019). The climatic boundary of the Arctic, i.e. the July $10^{\circ} \mathrm{C}$ isotherm, will move further north. The Arctic, as we currently know it, will shrink. The rise in temperature and greenhouse gases released from the thawing permafrost are already stimulating plant succession (Press, Callaghan \& Lee 1998; Maliniemi et al. 2018). Climate zones and ecosystems are moving north (Maliniemi et al. 2018). Available climate models predict an almost ice-free Arctic by mid-century (Wang \& Overland 2012; Jahn et al. 2016). Looking even further into the future, over the next few centuries, areas of the present Arctic may turn out to be a refuge for climate refugees. This would not be the first time during human civilisation that we would witness a migration of peoples. The green Arctic, at least in part, becomes a reality. Plant succession will enable shepherding. Sheep breeding and then cattle breeding will become possible. While, at present, the potential of Arctic agriculture is significantly limited by the periodical availability of sunlight (polar night and day periods), it is possible that, in the future, GMO cereals with a much shorter vegetation period will be available. Another option is to grow crops in greenhouses. What is not economically viable today due to the high energy costs may become economically 
viable and necessary in the future in light of improvements in alternative energy sources. The future of our civilisation may depend upon our ability to adapt (Klausen et al. 2015; O'Brien \& Selboe 2015), even in Arctic areas where, by that time, the climate will be better than in the overly warm temperate latitudes.

In the author's personal opinion it is difficult to assess the nature of the changes observed in the Arctic, and whether they are negative or positive. Change itself is usually negative for human beings, because they have to adapt to new conditions. Culture, traditions, technology developed and adapted to operate in ice do not work outside it, so it is necessary to develop innovations. While nature quickly adapts to new conditions, humans, according to their nature, will always look to the past with melancholy and longing. The problem in assessing the negative and positive effects of Arctic warming is the scale and perspective of observation. When evaluating Arctic warming in terms of its causes and our potential role in this, it is clearly negative. However, while the cause can be negative, the effects are not necessarily negative. Warmth is life; an ice-free Arctic is a livelier Arctic. Yes, there will be species exchange, expansion of some and decline of others, but we already know from history that human civilisation could only develop after the Ice Age had subsided. As I have mentioned many times in this paper, an ice-free Arctic could be a great opportunity for humankind, but this opportunity has a condition attached to it. Humans need to know and understand the processes taking place in the unfreezing Arctic. They need to learn to live in this environment anew. To understand environmental processes is to learn respect for nature. The future of humankind in the Arctic depends on a change in attitude towards the Arctic environment.
Humankind must stop its aggressive relationship with the Arctic, a relationship focused on exploitation over several centuries. Only sustainable development, based on strategic planning, detailed environmental analysis, the use of the latest technology and, above all, on moderation and respect for nature, will allow the effects of Arctic warming to be redirected to a positive path for our civilisations

\section{Funding}

This research was funded by National Science Centre grant no. 2018/29/N/ST10/01947: GROZA- Impact of climate-induced geohazards on Greenlandic coastal environments - case study of Disko Bay, Western Greenland.

\section{Acknowledgments}

This paper is dedicated to all Arctic communities, who suffer from climate change processes. I wrote this paper as a NAWA Iwanowska Programme Fellow (PPN/IWA/2018/1/00078) at the Leibniz Institute of Ecological Urban and Regional Development in Dresden. I would also like to thank my Supervisor, Dr hab. Mateusz Strzelecki, from the University of Wrocław for his support and guidance during my doctoral studies. Many thanks also to Professor Hugues Lantuit from the Alfred Wegener Institute for Polar and Marine Research for giving me the possibility to research the Canadian Arctic and thanks to Team Shrub from the University of Edinburgh for sharing the photograph of the flood.

\section{ORCID}

Marek Wojciech Jaskólski (1) https://orcid.org/0000-0001-6732-8973

\section{References}

Agence France-Presse, Fatal avalanche buries houses in Norway's Arctic Svalbard archipelago, 2015. Available from <https://www.theguardian.com/world/2015/dec/20/ fatal-avalanche-buries-houses-in-norways-arctic-svalbardarchipelago>. [11 November 2019].

Auswärtiges Amt, 2013, 'Leitlinien deutscher Arktispolitik, Verantwortung übernehmen, Chancen nutzen ['Guidelines of German Arctic policy, taking responsibility, seizing opportunities'], Referat für Arktispolitik, Berlin, Germany.

Andrew, R 2014, 'Socio-economic drivers of change in the Arctic', AMAP Technical Report, vol 9, Oslo, Norway.

Anisimov, O \& Orttung, R 2019, 'Climate change in Northern Russia through the prism of public perception', Ambio vol. 48(6), pp. 661-671.

Balser, AW, Jones, JB \& Gens, R 2014, 'Timing of retrogressive thaw slump initiation in the Noatak Basin, northwest Alaska', USA Journal of Geophysical Research: Earth Surface, vol. 119 , pp. 1106-1120.

Barnhart, KR, Anderson, RS, Overeem, I, Wobus, C, Clow, GD \& Urban, FE 2014, 'Modeling erosion of ice-rich permafrost bluffs along the Alaskan Beaufort Sea coast', Journal of Geophysical Research: Earth Surface, vol. 119, pp. 11551179.

Bendixen, M, Lønsmann Iversen, L, Bjørk, AA, Elberling, B, Westergaard-Nielsen, A, Overeem, I, Barnhart, KR, Abbas Khan, S, Box, JE, Abermann, J, Kangley, K \& Kroon, A 2017, 'Delta progradation in Greenland driven by increasing glacial mass loss', Nature, vol. 550, pp. 101-104.

Bennett, MM 2014, 'The Maritime Tiger: Exploring South Korea's interests and role in the Arctic', Strategic Analysis, vol. 38 pp. 886-903.
Bennett, MM 2018, 'Singapore: The "Global City" in a globalizing Arctic', Journal of Borderlands Studies, vol. 33, pp. 289-310.

Bergmann, M, Lutz, B, Tekman, MB \& Gutow, L 2017, 'Citizen scientists reveal: Marine litter pollutes Arctic beaches and affects wildlife', Marine Pollution Bulletin, vol. 125, pp. 535540.

Berton, P 2001, Klondike: The Last Great Gold Rush, 18961899, Revised Edition edn. Anchor, Canada.

Biskaborn, BK, Smith, SL, Noetzli, J, Matthes, H, Vieira, G, Streletskiy, DA, Schoeneich, P, Romanovsky, VE, Lewkowicz, AG, Abramov, A, Allard, M, Boike, J, Cable, WL, Christiansen, HH, Delaloye, R, Diekmann, B, Drozdov, D, Etzelmüller, B, Grosse, G, Guglielmin, M, Ingeman-Nielsen, $\mathrm{T}$, Isaksen, $\mathrm{K}$, Ishikawa, $\mathrm{M}$, Johansson, $\mathrm{M}$, Johannsson, $\mathrm{H}$, Joo, A, Kaverin, D, Kholodov, A, Konstantinov, P, Kröger, T, Lambiel, C, Lanckman, JP, Luo, D, Malkova, G, Meiklejohn, I, Moskalenko, N, Oliva, M, Phillips, M, Ramos, Sannel, ABK, Sergeev, D, Seybold, C, Skryabin, P, Vasiliev, A, Wu, Q, Yoshikawa, K, Zheleznyak, M \& Lantuit, H 2019, 'Permafrost is warming at a global scale', Nature Communications, vol. 10(1), pp. 1-11.

Bogen, J \& Bønsnes, TE 2003, 'Erosion and sediment transport in High Arctic rivers', Svalbard Polar Research, vol. 22, pp. 175-189.

Bogoyavlensky, D 2004, Arctic demography, Stefansson Institute, Iceland.

Bourriquen, M, Mercier, D, Baltzer, A, Fournier, J, Costa, S \& Roussel, E 2018, 'Paraglacial coasts responses to glacier retreat and associated shifts in river floodplains over decadal timescales (1966-2016), Kongsfjorden Svalbard', Land Degradation \& Development, vol. 29, pp. 4173-4185. 
Bowden, WB 2010, 'Climate change in the Arctic - permafrost, thermokarst, and why they matter to the Non-Arctic', World Geography Compass, vol. 4, pp. 1553-1566.

BMBF: Bundesministerium für Bildung und Forschung 2015, Schnelle Veräderungen in der Arktis, Polarforschung in globaler Verantwortung [Rapid changes in the Arctic, polar research in global responsibility] Referat System Erde, Berlin, Germany.

Bronen, R 2010, 'Forced migration of Alaskan indigenous communities due to climate change' in Environment, Forced Migration and Social Vulnerability, eds T Afifi \& J Jäger, Springer Berlin Heidelberg, Berlin, Heidelberg, pp. 87-98.

Bronen, R \& Chapin, FS 2013, 'Adaptive governance and institutional strategies for climate-induced community relocations in Alaska', Proceedings of the National Academy of Sciences, vol. 110, pp. 9320-9325.

Buchwał, A, Szczuciński, W, Strzelecki, MC \& Long AJ 2015, 'New insights into the 21 November 2000 tsunami in West Greenland from analyses of the treering structure of Salix glauca', Polish Polar Research, vol. 36, pp. 51-65.

Burn, CR 2017, 'Herschel Island (Qikiqtaryuk), Yukon's Arctic Island' in Landscapes and Landforms of Western Canada, ed O Slaymaker, Springer International Publishing, Cham, pp. 335-348.

Bystrowska, M, Wigger, K \& Liggett, D 2017, 'The use of Information and Communication Technology (ICT) in managing high Arctic tourism sites: A collective action perspective', Resources, vol. 6, pp. 33-50.

Carić, H \& Mackelworth, P 2014, 'Cruise tourism environmental impacts - The perspective from the Adriatic Sea', Ocean \& Coastal Management, vol. 102, pp. 350-363.

Carrington, D, Arctic stronghold of world's seeds flooded after permafrost melts, 2017. Available from <https:// www. theguardian.com/environment/2017/may/19/arcticstronghold-of-worlds-seeds-flooded-after-permafrostmelts>. [11 November 2019].

Cochran, P, Huntington, OH, Pungowiyi, C, Tom, S, Chapin, FS, Huntington, HP, Maynard, NG \& Trainor, SF 2013, 'Indigenous frameworks for observing and responding to climate change in Alaska', Climatic Change, vol. 120, pp. 557-567.

Dahl-Jensen, T, Larsen, LM, Pedersen, SAS, Pedersen, J, Jepsen, HF, Pedersen, G, Nielsen, T, Pedersen, AK, von Platen-Hallermund, F \& Weng, W 2004, 'Landslide and Tsunami 21 November 2000 in Paatuut, West Greenland', Natural Hazards, vol. 31, pp. 277-287.

Dahlke, HE, Lyon, SW, Stedinger, JR, Rosqvist, G \& Jansson, $P$ 2012. 'Contrasting trends in floods for two sub-arctic catchments in northern Sweden - does glacier presence matter?' Hydrology and Earth System Sciences vol. 16, pp. 2123-2141.

Dawson, J, Johnston, M \& Stewart, E 2017, 'The unintended consequences of regulatory complexity: The case of cruise tourism in Arctic Canada', Marine Policy, vol. 76, pp.71-78.

Debortoli, NS, Clark, DG, Ford, JD, Sayles, JS \& Diaconescu, EP 2019, 'An integrative climate change vulnerability index for Arctic aviation and marine transportation', Nature Communications, vol.10, no. 2596 .

Doré, G, Niu, F \& Brooks, H 2016, 'Adaptation methods for transportation infrastructure built on degrading permafrost', Permafrost and Periglacial Processes, vol. 27, pp. 352-364.

Duhaime, G, Chabot, M, Frechette, P, Robichaud, V \& Proulx, $S$ 2004, 'The impact of dietary changes among the Inuit of Nunavik (Canada): a socioeconomic assessment of possible public health recommendations dealing with food contamination', Risk Analysis, vol. 24, pp. 1007-1018.
Dzik, AJ 2014, 'Kangerlussuaq: evolution and maturation of a cultural landscape in Greenland', Bulletin of Geography Socio-economic Series, vol. 24, pp. 57-69.

Eckerstorfer, M \& Christiansen, HH 2012, 'Meteorology, topography and snowpack conditions causing two extreme mid-winter slush and wet slab avalanche Periods in high Arctic maritime Svalbard', Permafrost and Periglacial Processes, vol. 23, pp. 15-25.

Eckerstorfer, M, Farnsworth, WR \& Birkeland, KW 2014, 'Potential dry slab avalanche trigger zones on wind-affected slopes in central Svalbard', Cold Regions Science and Technology, vol. 99 , pp. $66-77$

Ermida, G 2014, 'Strategic decisions of international oil companies: Arctic versus other regions', Energy Strategy Reviews, vol. 2, pp. 265-272.

Evans, M 1999, Great World War II Battles in the Arctic, Contributions in Military Studies, 1 edn. Greenwood Press, Westport, USA.

Eyles, CH 1988, 'Glacially- and tidally-influenced shallow marine sedimentation of the late Precambrian Port Askaig Formation, Scotland', Palaeogeography, Palaeoclimatology, Palaeoecology, vol. 68, pp. 1-25.

Forbes, DL 2011, State of the Arctic Coast 2010. Arctic-scientific review and outlook, Helmholtz-Zentrum, Geesthacht, Germany.

Francis, JA \& Vavrus, SJ 2012, 'Evidence linking Arctic amplification to extreme weather in mid-latitudes', Geophysical Research Letters, vol. 39, no. 6.

Fritz, M, Vonk, JE \& Lantuit, H 2017, 'Collapsing Arctic coastlines', Nature Climate Change, vol. 7, pp. 6-7.

GISTEMP Team, GISS Surface Temperature Analysis (GISTEMP), version 4. NASA Goddard Institute for Space Studies, 2019. Available from: <https://data.giss.nasa.gov/ gistemp/>. [11 November 2019].

Gorokhovich, Y, Leiserowitz, A \& Dugan, A 2014, 'Integrating coastal vulnerability and community-based subsistence resource mapping in Northwest Alaska', Journal of Coastal Research, vol. 30, pp. 158-169.

Graham, RM, Itkin, P, Meyer, A, Sundfjord, A, Spreen, G, Smedsrud, LH, Liston, GE, Cheng, B, Cohen, L, Divine, D, Fer, I, Fransson, A, Gerland, S, Haapala, J, Hudson, SR, Johansson, AM, King, J, Merkouriadi, I, Peterson, AK, Provost, C, Randelhoff, A, Rinke, A, Rösel, A, Sennéchael, N, Walden, VP, Duarte, P, Assmy, P, Steen, H \& Granskog, MA 2019, 'Winter storms accelerate the demise of sea ice in the Atlantic sector of the Arctic', Ocean Scientific Reports, vol. 9 , no. 9222.

Harbitz, CB, Glimsdal, S, Løvholt, F, Kveldsvik, V, Pederse,n GK \& Jensen, A 2014, 'Rockslide tsunamis in complex fjords: From an unstable rock slope at Åkerneset to tsunami risk in western Norway', Coastal Engineering, vol. 88, pp. 101-122.

Heleniak, T 2015, Arctic population and migration, Nordic Council of Ministers, Copenhagen, Denmark.

Higman, B, Shugar, DH, Stark, CP, Ekström, G, Koppes, MN, Lynett, P, Dufresne, A, Haeussler, PJ, Geertsema, M, Gulick, S, Mattox, A, Venditti, JG, Walton, MAL, McCall, N, Mckittrick, E, Maclnnes, B, Bilderback, EL, Tang, H, Willis, MJ, Richmond, B, Reece, RS, Larsen, C, Olson, B, Capra, J, Ayca, A, Bloom, C, Williams, H, Bonno, D, Weiss, R, Keen, A, Skanavis, V \& Loso, M 2018, 'The 2015 landslide and tsunami in Taan Fiord, Alaska', Scientific Reports, vol. 8, no. 12993.

Higuera, PE, Chipman, ML, Barnes, JL, Urban, MA \& Hu, FS 2011, 'Variability of tundra fire regimes in Arctic Alaska: millennial-scale patterns and ecological implications', Ecological Applications, vol. 21 pp. 3211-3226. 
Hitch, TA \& Leberg, LP 2007, 'Breeding distributions of North American bird species moving north as a result of climate change conservation', Biology, vol. 21, pp. 534-539.

Hjort J, Karjalainen, O, Aalto, J, Westermann, S, Romanovsky, VE, Nelson, FE, Etzelmüller, B \& Luoto, M 2018, 'Degrading permafrost puts Arctic infrastructure at risk by mid-century', Nature Communications, vol. 9, no. 5147.

Holmgaard, SB, Thuestad, AE, Myrvoll, ER \& Barlindhaug 2019, 'Monitoring and managing human stressors to coastal cultural heritage in Svalbard', Humanities, vol. 8.

Hotez, PJ 2010, 'Neglected infections of poverty among the indigenous peoples of the Arctic' PLOS Neglected Tropical Diseases, vol. 4, no. 1.

Houseknecht, W \& Kenneth, J 2005, 'Oil and gas resources of the Arctic Alaska Petroleum Province' in Studies by the U.S. Geological Survey in Alaska. U.S. Geological Survey Professional Paper, pp 1-12.

IPCC 2014, Climate Change 2014: Synthesis Report. Contribution of Working Groups I, II and III to the Fifth Assessment Report of the Intergovernmental Panel on Climate Change, IPCC, Geneva, Switzerland.

IPCC 2019, Summary for Policymakers. IPCC Special Report on the Ocean and Cryosphere in a Changing Climate, IPCC, Geneva, Switzerland.

Irrgang, AM, Lantuit, H, Gordon, RR, Piskor A \& Manson GK 2019, 'Impacts of past and future coastal changes on the Yukon coast - threats for cultural sites, infrastructure, and travel routes', Arctic Science, vol. 5, pp. 107-126.

Isaev, VS, Koshurnikov, AV, Pogorelov, A, Amangurov, RM, Podchasov, O, Sergeev, DO, Buldovich, SM, Aleksyutina, DM, Grishakina, EA \& Kioka, A 2019, 'Cliff retreat of permafrost coast in south-west Baydaratskaya Bay, Kara Sea, during 2005-2016', Permafrost and Periglacial Processes, vol. 30, pp. 35-47.

Jahn, A, Kay, JE, Holland, MM \& Hall, DM 2016, 'How predictable is the timing of a summer ice-free Arctic?', Geophysical Research Letters, vol. 43, pp. 9113-9120.

Jaskólski, MW, Pawłowski, Ł \& Strzelecki, M 2017, 'Assessment of geohazards and coastal change in abandoned Arctic town, Pyramiden, Svalbard' in Cryosphere reactions against the background of environmental changes in contrasting highArctic conditions in Svalbard, ed. G Rachlewicz, Instutute of Geoecology and Geoinformation A. Mickiewicz University in Poznań Polar Report vol 2. Bogucki Wydawnictwo Naukowe, Poznań, Poland, pp 41-52.

Jaskólski, MW, Pawłowski, Ł \& Strzelecki, M 2018a, 'High Arctic coasts at risk-the case study of coastal zone development and degradation associated with climate changes and multidirectional human impacts in Longyearbyen (Adventfjorden,Svalbard)', LandDegradation\&Development, vol. 29 pp. 2514-2524.

Jaskólski, MW, Pawłowski, Ł, Strzelecki, MC, Zagórski, P, \& Lane TP 2018b, 'Trash on the arctic beach - case study of coastal pollution along Calypsostranda, Bellsund, Svalbard', Polish Polar Research, vol. 39 pp. 211-224.

Jones, BM, Stoker, JM, Gibbs, AE, Grosse, G, Romanovsky, VE, Douglas, TA, Kinsman NEM \& Richmond, BM 2013, 'Quantifying landscape change in an arctic coastal lowland using repeat airborne LiDAR', Environmental Research Letters, vol. 8, no. 4.

Jones, BM, Grosse, G, Arp, CD, Miller, E, Liu, L, Hayes, DJ \& Larsen, CF 2015, 'Recent Arctic tundra fire initiates widespread thermokarst development', Scientific Reports, vol. 5 , no. 15865

Jørgensen, AS \& Andreasen, F 2007, 'Mapping of permafrost surface using ground-penetrating radar at Kangerlussuaq
Airport, western Greenland', Cold Regions Science and Technology, vol. 48, pp.64-72.

Kaltenborn, BP \& Emmelin, L 1993, 'Tourism in the high north: Management challenges and recreation opportunity spectrum planning in Svalbard, Norway', Environmental Management, vol. 17, no. 41.

Kane, DL, McNamara, JP, Yang, D, Olsson, PQ \& Gieck, RE 2003, 'An extreme rainfall/runoff event in Arctic Alaska', Journal of Hydrometeorology, vol. 4, pp. 1220-1228.

Karjalainen, O, Aalto, J, Luoto, M, Westermann, S, Romanovsky, VE, Nelson, FE, Etzelmüller, B \& Hjort, J 2019, 'Circumpolar permafrost maps and geohazard indices for near-future infrastructure risk assessments', Scientific Data, vol. 6, no.190037.

Kasprzak, M, Łopuch, M, Głowacki, T \& Milczarek, W 2020, 'Evolution of near-shore outwash fans and permafrost spreading under their surface: A case study from Svalbard', Remote Sensing, vol. 12, pp. 27.

Kenny, MJ 2017, Urban planning in the Arctic: Historic uses \& the potential for a resilient urban future, University of Lapland, Rovaniemi, Finland.

Khalturin, VI, Rautian, TG, Richards, PG \& Leith, WS 2005, 'A review of nuclear testing by the Soviet Union at Novaya Zemlya, 1955-1990', Science \& Global Security, vol. 13, pp. $1-42$.

Khon, VC, Mokhov, II, Latif, M, Semenov, VA \& Park, W 2010, 'Perspectives of Northern Sea Route and Northwest Passage in the twenty-first century', Climatic Change, vol. 100, pp. 757-768.

Klausen, JE, Saglie, IL, Stokke, KB \& Winsvold, M 2015, 'Planning for climate change adaptation in urban areas' in The Adaptive Challenge of Climate Change, eds E Selboe \& K O'Brien, Cambridge University Press, Cambridge, pp. 63-80.

Kontorovich, A 2015, 'Oil and gas of the Russian Arctic: History of development in the 20th century, resources and strategy for the 21st century', Science First Hand, vol. 41, no. 2.

Lackenbauer, PW \& Farish, M 2007, 'The Cold War on Canadian soil: militarizing a northern environment', Environmental History, vol. 12, pp. 920-950.

Lantuit, H, Overduin, PP, Couture, N, Wetterich, S, Aré, F, Atkinson, D, Brown, J, Cherkashov, G, Drozdov, D, Forbes, DL, Graves-Gaylord, A, Grigoriev, M, Hubberten, HW, Jordan, J, Jorgenson, T, Ødegård, RS, Ogorodov, S, Pollard, WH, Rachold, V, Sedenko, S, Solomon, S, Steenhuisen, F, Streletskaya, I \& Vasiliev, A 2011, 'The Arctic coastal dynamics database: A new classification scheme and statistics on Arctic permafrost coastlines', Estuaries and Coasts, vol. 35, pp. 383-400.

Lantz, TC \& Kokelj, SV 2008, 'Increasing rates of retrogressive thaw slump activity in the Mackenzie Delta region, N.W.T., Canada', Geophysical Research Letters vol. 35, no. L06502, pp. 1-5.

Lewkowicz, AG \& Way, RB 2019, 'Extremes of summer climate trigger thousands of thermokarst landslides in a High Arctic environment', Nature Communications, vol. 10, no.1329, pp. $1-11$.

Lenssen, NJL, Schmidt, GA, Hansen, JE, Menne, MJ, Persin, A, Ruedy, R \& Zyss, D 2019, 'Improvements in the GISTEMP Uncertainty Model', Journal of Geophysical Research: Atmospheres, vol. 124, pp. 6307-6326.

Łuszczuk, M 2015, 'Changing foreign policy roles in the changing Arctic' in Global Challenges in Arcic Region. Sovereignty, environment and geopolitical balance, ed. ES Conde, Routledge, London - New York. 
Maki, AW 1992, 'Of measured risks: The environmental impacts of the Prudhoe Bay, Alaska, oil field', Environmental Toxicology and Chemistry, vol. 11, pp. 1691-1707.

Maliniemi, T, Kapfer, J, Saccone, P, Skog, A \& Virtanen R 2018, 'Long-term vegetation changes of treeless heath communities in northern Fennoscandia: Links to climate change trends and reindeer grazing', Journal of Vegetation Science, vol. 29, pp. 469-479.

McCannon, J 2012, A History of the Arctic: Nature, exploration and exploitation. Reaktion Books, London, UK.

McFadden, TT \& Bennett, FL 1991, Construction in cold regions-a guide for planners, engineers, contractors, and managers, Wiley-Interscience, Hoboken, USA.

McGwin, K, 2017, A strategy to double Nuuk's population begins with a new housing district. Available from: <https://www. arctictoday.com/a-strategy-to-double-nuuks-populationbegins-with-a-new-housing-district/ >. [11 November 2019].

Mercier, D \& Laffly, D 2005, 'Actual paraglacial progradation of the coastal zone in the Kongsfjorden area, western Spitsbergen (Svalbard)', Geological Society, vol. 242, London, Special Publications, pp. 111-117.

Miller, DJ 1960, 'The Alaska earthquake of July 10, 1958: Giant wave in Lituya Bay', Bulletin of the Seismological Society of America, vol. 50, pp. 253-266.

Miller, J 2003, The North Atlantic Front: Orkney, Shetland, Faroe, and Iceland at War, Birlinn, Edinburgh.

Morrison, D 1989, 'Radiocarbon dating Thule Culture', Arctic Anthropology, vol. 26, pp. 48-77.

Næss, I 2017, Avalanche in Longyearbyen 21 February 2017. Available from: <https://www.unis.no/avalanchelongyearbyen-21-february-2017/>. [11 November 2019].

Nicu, IC, Stalsberg, K, Rubensdotter, L, Martens, VV \& Flyen, AC 2020, 'Coastal erosion affecting cultural heritage in Svalbard. A case study in Hiorthhamn (Adventfjorden) -An Abandoned mining settlement', Sustainability vol. 12 no. 2306, pp. 1-21.

Notz, D \& Stroeve, J 2018, 'The trajectory towards a seasonally ice-free Arctic Ocean', Current Climate Change Reports, vol. 4, pp. 407-416.

Nyman, E, Galvao, CB, Mileski, J \& Tiller, R 2019, 'The Svalbard archipelago: an exploratory analysis of port investment in the context of the new arctic routes', Maritime Studies, vol. 19, pp. 1-13.

O'Brien, K \& Selboe, E 2015, 'Climate change as an adaptive challenge' in The Adaptive Challenge of Climate Change, eds $\mathrm{E}$ Selboe, K O'Brien K,Cambridge University Press, Cambridge, pp 1-23.

Obu, J, Lantuit, H, Grosse, G, Günther, F, Sachs, T, Helm, V, Fritz, M 2017, 'Coastal erosion and mass wasting along the Canadian Beaufort Sea based on annual airborne LiDAR elevation data', Geomorphology, vol. 293, pp. 331-346.

Overduin, PP, Strzelecki, MC, Grigoriev, MN, Couture, N, Lantuit, H, St-Hilaire-Gravel, D, Günther, F \& Wetterich, S 2014, 'Coastal changes in the Arctic', Geological Society, London, Special Publications vol. 388, pp. 103-129.

Overeem, I, Anderson, RS, Wobus, CW, Clow, GD, Urban, FE, Matell, N 2011, 'Sea ice loss enhances wave action at the Arctic coast', Geophysical Research Letters, vol. 38, no.L17503, pp. 1-6.

Pengelly, M 2019, Trump 'crazy like a fox' in suggesting Greenland purchase, says Republican. Available from: $<$ https://www. theguardian.com/us-news/2019/aug/26/ trump-crazy-like-a-fox-greenland-purchase-senator-tomcotton>. [11 November 2019].

Peterson, BJ, Holmes, RM, McClelland, JW, Vörösmarty, CJ, Lammers, RB, Shiklomanov, AI, Shiklomanov, IA \&
Rahmstorf, S 2002, 'Increasing river discharge to the Arctic', Ocean Science, vol. 298, pp. 2171-2173.

Press, CM, Callaghan, TV \& Lee, JA 1998, 'How will European Arctic ecosystems respond to projected global environmental change?', Ambio, vol. 27, pp. 306-311.

Prno, J, Bradshaw, B, Wandel, J, Pearce, T, Smit, B \& Tozer, L 2011, 'Community vulnerability to climate change in the context of other exposure-sensitivities in Kugluktuk, Nunavut', Polar Research, vol. 30, no. 7363, pp. 1-21.

Rachlewicz, G 2009, 'River floods in glacier-covered catchments of the High Arctic: Billefjorden-Wijdefjorden, Svalbard Norsk Geografisk Tidsskrift', Norwegian Journal of Geography, vol. 63, pp. 115-122.

Rahman, NSF, Saharuddin, AH \& Rasdi, R 2014, 'Effect of the Northern Sea route opening to the shipping activities at Malacca Straits', International Journal of e-Navigation and Maritime Economy, vol. 1, pp. 85-98.

Radosavljevic, B, Lantuit, H, Pollard, W, Overduin, P, Couture, N, Sachs, T, Helm, V \& Fritz, M 2016, 'Erosion and floodingthreats to coastal infrastructure in the Arctic: A case study from Herschel Island, Yukon Territory', Canada Estuaries and Coasts vol. 39, pp. 900-915.

Robinson, M 1966, The coldest crucible: Arctic exploration and American culture. University of Chicago Press, Chicago, USA.

Rowley G 1940, 'The Dorset Culture of the Eastern Arctic', American Anthropologist, vol. 42, pp. 490-499.

Schraeder, RL, Riddle, CH \& Slater, WH 1996, 'Route location/ sitting: A review of practices' in Roads and Airfields in Cold Regions, ed. TS Vinson, Technical council on cold regions engineering monograph, ASCE Publications, pp. 23-57.

Schuur, EAG, Vogel, JG, Crummer, KG, Lee, H, Sickman, JO \& Osterkamp, TE 2009, 'The effect of permafrost thaw on old carbon release and net carbon exchange from tundra', Nature, vol. 459, pp. 556-559.

Screen, JA, Simmonds, I \& Keay, K 2011, 'Dramatic interannual changes of perennial Arctic sea ice linked to abnormal summer storm activity', Journal of Geophysical Research: Atmospheres, vol. 116, no. D15105, pp. 1-10.

Sessford, E, Bæverfjord, M \& Hormes, A 2015, 'Terrestrial processes affecting unlithified coastal erosion disparities in central fjords of Svalbard', Polar Research, vol. 34, no. 24122, pp. 1-17.

Shiklomanov, NI, Streletskiy, DA, Grebenets, VI \& Suter, L 2017, 'Conquering the permafrost: urban infrastructure development in Norilsk, Russia' Polar Geography, vol. 40, pp. 273-290.

Shnyparkov, A, Fuchs, S, Sokratov, S, Koltermann, P, Seliverstov, Y \& Vikulina, M 2012, 'Theory and practice of individual snow avalanche risk assessment in the Russian Arcic', Geography, Environment, Sustainability, vol. 5, pp. 64-81.

Siminski, J 2013, Russia reactivates military airfield in the Arctic Region after 20 years. Available from: <https://www. businessinsider.com/russia-reactivates-arctic-military-base2013-12? IR=T>. [11 November 2019].

Singh, R 2013, 'Chapter 2 - design and construction' in Arctic Pipeline Planning, ed R Singh, Gulf Professional Publishing, Boston, pp 9-42.

Staalesen, A 2019, Arctic summer 2019: record-beating heat, dramatic ice loss and raging wildfires. Available from: $<$ https://thebarentsobserver.com/en/arktika/2019/07/worldswarmest-june-ever-heatwave-raged-across-parts-arctic>. [11 November 2019].

Stange, R 2018, Spitsbergen Svalbard. A complete guide around the Arctic Archipelago, 6 edn. Stange, Rolf, Dresden, Germany. 
Steinecke, K 1999, 'Urban climatological studies in the Reykjavík subarctic environment, Iceland', Atmospheric Environment, vol. 33, pp. 4157-4162.

Stephen, K 2018, 'Societal impacts of a rapidly changing Arctic', Current Climate Change Reports, vol. 4, pp. 223-237.

Stoffel, M, Bollschweiler, M \& Hassler, GR 2006, 'Differentiating past events on a cone influenced by debris-flow and snow avalanche activity - a dendrogeomorphological approach', Earth Surface Processes and Landforms, vol. 31, pp. 1424-

Streletskiy, DA, Suter LJ, Shiklomanov, NI, Porfiriev, BN \& Eliseev, DO 2019, 'Assessment of climate change impacts on buildings, structures and infrastructure in the Russian regions on permafrost', Environmental Research Letters, vol. 14 , no. 025003 , pp. 1-15.

Stroeve, JC, Maslanik, J, Serreze, MC, Rigor, I, Meier, W \& Fowler, C 2011, 'Sea ice response to an extreme negative phase of the Arctic Oscillation during winter 2009/2010', Geophysical Research Letters, vol. 38, no. L02502, pp. 1-6.

Strzelecki, M 2011, 'Cold shores in warming times - current state and future challenges in High Arctic', Coastal Geomorphological Studies, vol. 30, no. 101, pp. 1-13.

Strzelecki, MC, Małecki, J \& Zagórski, P 2015, 'The Influence of Recent Deglaciation and Associated Sediment Flux on the Functioning of Polar Coastal Zone - Northern Petuniabukta, Svalbard' in Sediment Fluxes in Coastal Areas, eds M Maanan \& M Robin M, Springer Netherlands, Dordrecht, pp 23-45.

Strzelecki, MC, Kasprzak, M, Lim, M, Swirad, Z, Jaskólski, M, Pawłowski, Ł \& Modzel, P 2017 'Cryo-conditioned rocky coast systems: A case study from Wilczekodden, Svalbard', Science of The Total Environment, vol. 607-608 pp. 443453.

Strzelecki, MC \& Jaskólski, MW 2020, 'Arctic tsunamis threaten coastal landscapes and communities - survey of Karrat Isfjord 2017 tsunami effects in Nuugaatsiaq, western Greenland', Natural Hazards and Earth System Sciences, vol. 20 pp. 2521-2534.

Susskind, L, Rumore, D, Hulet, C \& Field, P 2015, Managing climate risks in coastal communities - strategies for engagement, readiness and adaptation, Anthem Press, London.

Syvitski, JPM 1989, 'On the deposition of sediment within glacierinfluenced fjords: Oceanographic controls', Marine Geology, vol. 85, pp. 301-329.

Taylor, WE 1963, 'Hypotheses on the Origin of Canadian Thule Culture', American Antiquity, vol. 28, pp. 456-464.

Teufel, B \& Sushama, L 2019, 'Abrupt changes across the Arctic permafrost region endanger northern development', Nature Climate Change, vol. 9, pp. 858-862.

Van Tatenhove, FGM \& Olesen, OB 1994, 'Ground temperature and related permafrost characteristics in west greenland', Permafrost and Periglacial Processes, vol. 5, pp. 199-215.

Vavrus, JS, Holland, MM, Jahn, A, Bailey, AD \& Blazey, AB 2012, 'Twenty-first-century Arctic climate change in CCSM4', Journal of Climate, vol. 25, pp. 2696-2710.

Vermaire, JC, Pisaric, MFJ, Thienpont, JR, Courtney-Mustaphi, CJ, Kokelj, SV \& Smol, JP 2013, 'Arctic climate warming and sea ice declines lead to increased storm surge activity', Geophysical Research Letters, vol. 40, pp. 1386-1390.

Walker, DA \& Everett, KR 1987, 'Road dust and its environmental impact on Alaskan Taiga and Tundra', Arctic and Alpine Research, vol. 19, pp. 479-489.
Walker, DA, Kofinas, G, Raynolds, M, Kanevskiy, M, Shur, Y, Ambrosius, K, Buchhorn, M, Matayshak, G, Romanovsky, $V$ \& Wirth, L 2015, 'Cumulative effects of infrastructure and climate in the permafrost landscapes of the Prudhoe Bay oilfield, Alaska' in Rapid Arctic Transitions due to Infrastructure and Climate (RATIC):A contribution to ICARP III, eds DAP Walker \& JL Peirce, University of Alaska, Fairbanks, Alaska, pp. 2-11.

Waltham, T 2007, 'Klondike Gold', Geology Today, vol. 23, pp. 219-226.

Wang, M \& Overland, JE 2012, 'A sea ice free summer Arctic within 30 years: An update from CMIP5 models', Geophysical Research Letters, vol. 39, no. L18501, pp. 1-6.

Weiss, R, Fritz, HM \& Wünnemann, K 2009, 'Hybrid modeling of the mega-tsunami runup in Lituya Bay after half a century', Geophysical Research Letters, vol. 36, no. L09602, pp. 1-6.

Welch, C 2019, Climate change has finally caught up to this Alaska village. Available from: <https://www.nationalgeographic. com/science/2019/10/climate-change-finally-caught-upto-this-alaska-village/?fbclid=IwAR3QrguHKctdqV1yeiP LXi5AOKPUk2veFljwxqIBH_TKdCvR78quhytt6GQ>. [11 November 2019].

Wilson, E \& Piper, J 2010, Spatial planning and climate change, Routledge, Abingdon, UK.

Wobus, C, Anderson, R, Overeem, I, Matell, N, Clow, G \& Urban, F 2011, 'Thermal erosion of a permafrost coastline: Improving process-based models using time-lapse photography', Arctic, Antarctic, and Alpine Research, vol. 43, pp. 474-484.

WWF 2012, WWF Living Planet Report, Gland, Switzerland.

Zagórski, P, Rodzik, J, Moskalik, M, Strzelecki MC, Lim, M, Błaszczyk, M, Promińska, A, Kruszewski, G, Styszyńska, A \& Malczewski, A 2015, 'Multidecadal (1960-2011) shoreline changes in Isbjørnhamna (Hornsund, Svalbard)', Polish Polar Research vol 36, no. 4, pp. 369-390.

Zagórski, P, Jarosz, K \& Superson, J 2020, 'Integrated assessment of shoreline change along the calypsostranda (Svalbard) from remote sensing, field survey and GIS', Marine Geodesy vol 43, no. 5, pp. 433-471.

Zajączkowski, M, Szczucinski, W \& Bojanowski, R 2004, 'Recent changes in sediment accumulation rates in Adventfjorden, Svalbard', Oceanologia, vol. 46, pp. 217-231.

Zhen, L 2018, China breaks the Arctic ice with launch of new research vessel Snow Dragon II. Available from <https:// www.scmp.com/news/china/military/article/2163784/ china-breaks-arctic-ice-launch-new-research-vessel>. [11 November 2019]. 
Appendix

Appendix 1. List of all analysed and presented settlements in Figure 1.

\begin{tabular}{|c|c|c|c|c|c|c|}
\hline Name & Belonging & Latitude & Longitude & Population & Census Year & Primary Function \\
\hline Illorsuit & Greenland & $71^{\circ} 14 \mathrm{~N}$ & $53^{\circ} 34 \mathrm{~W}$ & 101 & 2016 & Fishery \& Hunting \\
\hline Sachs Harbour & Canada & $71^{\circ} 59 \mathrm{~N}$ & $125^{\circ} 14 \mathrm{~W}$ & 103 & 2016 & Fishery \& Hunting \\
\hline Yukagir & Russia & $71^{\circ} 46 \mathrm{~N}$ & $139^{\circ} 53 \mathrm{E}$ & 128 & 2014 & Fishery \& Hunting \\
\hline Grise Fiord & Canada & $76^{\circ} 25 \mathrm{~N}$ & $82^{\circ} 53 \mathrm{~W}$ & 129 & 2016 & Fishery \& Hunting \\
\hline Ny-Ålesund & Norway & $78^{\circ} 55 \mathrm{~N}$ & $11^{\circ} 55 \mathrm{E}$ & 130 & 2010 & Research \\
\hline Skarsvåg & Norway & $71^{\circ} 8 \mathrm{~N}$ & $25^{\circ} 49 \mathrm{E}$ & 141 & 2014 & Fishery \& Hunting \\
\hline Innaarsuit & Greenland & $73^{\circ} 11 \mathrm{~N}$ & $56^{\circ} \mathrm{OW}$ & 153 & 2014 & Fishery \& Hunting \\
\hline Ukkusissat & Greenland & $71^{\circ} 2 \mathrm{~N}$ & $51^{\circ} 53 \mathrm{~W}$ & 155 & 2014 & Fishery \& Hunting \\
\hline Aappilattoq & Greenland & $72^{\circ} 53 \mathrm{~N}$ & $55^{\circ} 36 \mathrm{~W}$ & 169 & 2014 & Fishery \& Hunting \\
\hline Kangersuatsiaq & Greenland & $72^{\circ} 22 \mathrm{~N}$ & $55^{\circ} 33 \mathrm{~W}$ & 173 & 2014 & Fishery \& Hunting \\
\hline Saqqaq & Greenland & $70^{\circ} \mathrm{ON}$ & $51^{\circ} 56 \mathrm{~W}$ & 173 & 2014 & Tourism \\
\hline Qaarsut & Greenland & $70^{\circ} 43 \mathrm{~N}$ & $52^{\circ} 38 \mathrm{~W}$ & 196 & 2010 & Tourism \\
\hline Resolute & Canada & $74^{\circ} 41 \mathrm{~N}$ & $94^{\circ} 49 \mathrm{~W}$ & 198 & 2012 & Military \\
\hline Gamvik & Norway & $71^{\circ} 3 \mathrm{~N}$ & $28^{\circ} 14 \mathrm{E}$ & 200 & 2010 & Fishery \\
\hline Nuussuaq & Greenland & $74^{\circ} 6 \mathrm{~N}$ & $57^{\circ} 3 \mathrm{~W}$ & 202 & 2015 & Fishery \& Hunting \\
\hline Saattut & Greenland & $70^{\circ} 48 \mathrm{~N}$ & $51^{\circ} 38 \mathrm{~W}$ & 212 & 2010 & Fishery \& Hunting \\
\hline Ikerasak & Greenland & $70^{\circ} 30 \mathrm{~N}$ & $51^{\circ} 18 \mathrm{~W}$ & 238 & 2014 & Fishery \& Hunting \\
\hline Tasiusaq & Greenland & $73^{\circ} 22 \mathrm{~N}$ & $56^{\circ} 3 \mathrm{~W}$ & 248 & 2010 & Fishery \& Hunting \\
\hline Kaktovik & USA & $70^{\circ} 7 \mathrm{~N}$ & $143^{\circ} 36 \mathrm{~W}$ & 256 & 2018 & Fishery \& Hunting \\
\hline Paulatuk & Canada & $69^{\circ} 21 \mathrm{~N}$ & $124^{\circ} 4 \mathrm{~W}$ & 265 & 2016 & Fishery \& Hunting \\
\hline Ulukhaktok & Canada & $70^{\circ} 44 \mathrm{~N}$ & $117^{\circ} 46 \mathrm{~W}$ & 396 & 2016 & Fishery \& Hunting \\
\hline Kullorsuaq & Greenland & $74^{\circ} 34 \mathrm{~N}$ & $57^{\circ} 13 \mathrm{~W}$ & 448 & 2013 & Fishery \& Hunting \\
\hline Ittoqqortoormiit & Greenland & $70^{\circ} 29 \mathrm{~N}$ & $21^{\circ} 58 \mathrm{~W}$ & 452 & 2013 & Fishery \& Hunting \\
\hline Barentsburg & Russia & $78^{\circ} 4 \mathrm{~N}$ & $14^{\circ} 30 \mathrm{E}$ & 471 & 2015 & Industry \\
\hline Bykovsky & Russia & $72^{\circ} \mathrm{ON}$ & $129^{\circ} 6 \mathrm{E}$ & 514 & 2016 & Fishery \& Hunting \\
\hline Nayba & Russia & $70^{\circ} 50 \mathrm{~N}$ & $130^{\circ} 45 \mathrm{E}$ & 522 & 2010 & Fishery \& Hunting \\
\hline Kangaatsiaq & Greenland & $68^{\circ} 18 N$ & $53^{\circ} 27 \mathrm{~W}$ & 552 & 2011 & Fishery \& Hunting \\
\hline Wainwright & USA & $70^{\circ} 38 \mathrm{~N}$ & $160^{\circ} \mathrm{OW}$ & 556 & 2010 & Fishery \& Hunting \\
\hline Kangaatsiaq & Greenland & $68^{\circ} 18 \mathrm{~N}$ & $53^{\circ} 27 \mathrm{~W}$ & 558 & 2013 & Fishery \& Hunting \\
\hline Qaanaaq (Thule) & Greenland & $77^{\circ} 30 \mathrm{~N}$ & $69^{\circ} 13 \mathrm{~W}$ & 656 & 2013 & Military \\
\hline Point Hope & USA & $68^{\circ} 20 \mathrm{~N}$ & $166^{\circ} 45 \mathrm{~W}$ & 709 & 2017 & Fishery \& Hunting \\
\hline Mehamn & Norway & $71^{\circ} 2 \mathrm{~N}$ & $27^{\circ} 50 \mathrm{E}$ & 779 & 2017 & Fishery \\
\hline Qeqertarsuaq & Greenland & $69^{\circ} 14 \mathrm{~N}$ & $53^{\circ} 33 \mathrm{~W}$ & 856 & 2018 & Fishery \& Hunting \\
\hline Arctic Bay & Canada & $73^{\circ} 2 \mathrm{~N}$ & $85^{\circ} 9 \mathrm{~W}$ & 868 & 2016 & Fishery \& Hunting \\
\hline Tuktoyaktuk & Canada & $69^{\circ} 26 \mathrm{~N}$ & $133^{\circ} 2 \mathrm{~W}$ & 898 & 2016 & Industry \\
\hline
\end{tabular}


MISCELLANEA GEOGRAPHICA - REGIONAL STUDIES ON DEVELOPMENT

Vol. 25 • No. 2 - 2021 • pp. 127-143 • ISSN: 2084-6118 • DOI: 10.2478/mgrsd-2020-0036

\begin{tabular}{|c|c|c|c|c|c|c|}
\hline Name & Belonging & Latitude & Longitude & Population & Census Year & Primary Function \\
\hline Havøysund & Norway & $70^{\circ} 59 \mathrm{~N}$ & $24^{\circ} 39 \mathrm{E}$ & 1027 & 2012 & Fishery \\
\hline Taloyoak & Canada & $69^{\circ} 32 \mathrm{~N}$ & $93^{\circ} 31 \mathrm{~W}$ & 1029 & 2016 & Fishery \& Hunting \\
\hline Upernavik & Greenland & $72^{\circ} 47 \mathrm{~N}$ & $56^{\circ} 9 \mathrm{~W}$ & 1065 & 2018 & Fishery \& Hunting \\
\hline Berlevåg & Norway & $70^{\circ} 51 \mathrm{~N}$ & $24^{\circ} 5 \mathrm{E}$ & 1113 & 2005 & Fishery \\
\hline Qasigiannguit & Greenland & $68^{\circ} 49 \mathrm{~N}$ & $51^{\circ} 11 \mathrm{~W}$ & 1171 & 2013 & Fishery \\
\hline Dikson & Russia & $73^{\circ} 30 \mathrm{~N}$ & $80^{\circ} 31 \mathrm{E}$ & 1200 & 2004 & Maritime Transport \\
\hline Qasigiannguit & Greenland & $68^{\circ} 49 \mathrm{~N}$ & $51^{\circ} 11 \mathrm{~W}$ & 1217 & 2011 & Fishery \\
\hline Uummannaq & Greenland & $70^{\circ} 40 \mathrm{~N}$ & $52^{\circ} 7 \mathrm{~W}$ & 1282 & 2013 & Tourism \\
\hline Snezhnogorsk & Russia & $69^{\circ} 11 \mathrm{~N}$ & $33^{\circ} 13 \mathrm{E}$ & 1430 & 2010 & Military \\
\hline Pond Inlet & Canada & $72^{\circ} 42 \mathrm{~N}$ & $77^{\circ} 57 \mathrm{~W}$ & 1617 & 2016 & Industry \\
\hline Cambridge Bay & Canada & $69^{\circ} 7 \mathrm{~N}$ & $105^{\circ} 3 \mathrm{~W}$ & 1766 & 2016 & Maritime Transport \\
\hline Rypefjord & Norway & $70^{\circ} 38 \mathrm{~N}$ & $23^{\circ} 40 \mathrm{E}$ & 1838 & 2017 & Fishery \\
\hline Belushya Guba & Russia & $71^{\circ} 32 \mathrm{~N}$ & $52^{\circ} 19 \mathrm{E}$ & 1972 & 2010 & Military \\
\hline Vardø & Norway & $70^{\circ} 22 \mathrm{~N}$ & $31^{\circ} 1 \mathrm{E}$ & 2110 & 2018 & Fishery \\
\hline Longyearbyen & Norway & $78^{\circ} 13 N$ & $15^{\circ} 38 \mathrm{E}$ & 2144 & 2015 & Tourism \\
\hline Prudhoe Bay & USA & $70^{\circ} 19 \mathrm{~N}$ & $148^{\circ} 30 \mathrm{~W}$ & 2174 & 2010 & Industry \\
\hline Båtsfjord & Norway & $70^{\circ} 38 \mathrm{~N}$ & $29^{\circ} 43 \mathrm{E}$ & 2185 & 2005 & Fishery \\
\hline Melbu & Norway & $68^{\circ} 30 \mathrm{~N}$ & $14^{\circ} 50 \mathrm{E}$ & 2202 & 2018 & Fishery \\
\hline Lakselv & Norway & $70^{\circ} 3 \mathrm{~N}$ & $24^{\circ} 57 \mathrm{E}$ & 2283 & 2017 & Fishery \\
\hline Honningsvåg & Norway & $70^{\circ} 58 \mathrm{~N}$ & $25^{\circ} 58 \mathrm{E}$ & 2484 & 2017 & Maritime Transport \\
\hline Andenes & Norway & $69^{\circ} 19 \mathrm{~N}$ & $16^{\circ} 8 \mathrm{E}$ & 2694 & 2018 & Military \\
\hline Skjervøy & Norway & $70^{\circ} 2 \mathrm{~N}$ & $20^{\circ} 58 \mathrm{E}$ & 2881 & 2014 & Fishery \\
\hline Aasiaat & Greenland & $68^{\circ} 43 \mathrm{~N}$ & $52^{\circ} 39 \mathrm{~W}$ & 3112 & 2017 & Fishery \& Hunting \\
\hline Stokmarknes & Norway & $68^{\circ} 33 \mathrm{~N}$ & $14^{\circ} 54 \mathrm{E}$ & 3367 & 2018 & Maritime Transport \\
\hline Kirkenes & Norway & $69^{\circ} 43 \mathrm{~N}$ & $30^{\circ} 3 \mathrm{E}$ & 3529 & 2018 & Fishery \& Hunting \\
\hline Leknes & Norway & $68^{\circ} 8 \mathrm{~N}$ & $13^{\circ} 36 \mathrm{E}$ & 3556 & 2018 & Maritime Transport \\
\hline Pevek & Russia & $69^{\circ} 42 \mathrm{~N}$ & $170^{\circ} 17 \mathrm{E}$ & 4547 & 2017 & Industry \\
\hline Finnsnes & Norway & $69^{\circ} 13 N$ & $17^{\circ} 58 \mathrm{E}$ & 4658 & 2017 & Administration \\
\hline Utqiag̉vik (Barrow) & USA & $71^{\circ} 18 \mathrm{~N}$ & $156^{\circ} 44 \mathrm{~W}$ & 4680 & 2004 & Industry \\
\hline Svolvær & Norway & $68^{\circ} 14 \mathrm{~N}$ & $14^{\circ} 34 \mathrm{E}$ & 4720 & 2018 & Fishery \\
\hline Ilulissat & Greenland & $69^{\circ} 13 \mathrm{~N}$ & $51^{\circ} 6 \mathrm{~W}$ & 4905 & 2018 & Administration \\
\hline Vidyayevo & Russia & $69^{\circ} 19 \mathrm{~N}$ & $32^{\circ} 48 \mathrm{E}$ & 5985 & 2018 & Military \\
\hline Vads $\varnothing$ & Norway & $70^{\circ} 4 \mathrm{~N}$ & $29^{\circ} 44 \mathrm{E}$ & 6223 & 2014 & Fishery \\
\hline Fauske & Norway & $67^{\circ} 15 \mathrm{~N}$ & $15^{\circ} 23 \mathrm{E}$ & 9556 & 2014 & Administration \\
\hline Sortland & Norway & $68^{\circ} 41 \mathrm{~N}$ & $15^{\circ} 24 \mathrm{E}$ & 10129 & 2014 & Administration \\
\hline Hammerfest & Norway & $70^{\circ} 39 \mathrm{~N}$ & $23^{\circ} 41 \mathrm{E}$ & 10287 & 2014 & Industry \\
\hline Gadzhiyevo & Russia & $69^{\circ} 15 \mathrm{~N}$ & $33^{\circ} 21 \mathrm{E}$ & 11068 & 2010 & Military \\
\hline
\end{tabular}




\begin{tabular}{|c|c|c|c|c|c|c|}
\hline Name & Belonging & Latitude & Longitude & Population & Census Year & Primary Function \\
\hline Narvik & Norway & $68^{\circ} 26 \mathrm{~N}$ & $17^{\circ} 25 \mathrm{E}$ & 14141 & 2018 & Administration \\
\hline Polyarny & Russia & $69^{\circ} 12 \mathrm{~N}$ & $33^{\circ} 27 \mathrm{E}$ & 16468 & 2014 & Military \\
\hline Alta & Norway & $69^{\circ} 58 \mathrm{~N}$ & $23^{\circ} 17 \mathrm{E}$ & 19822 & 2014 & Industry \\
\hline Harstad & Norway & $68^{\circ} 47 \mathrm{~N}$ & $16^{\circ} 32 \mathrm{E}$ & 24820 & 2018 & Industry \\
\hline Severomorsk & Russia & $69^{\circ} 4 \mathrm{~N}$ & $33^{\circ} 25 \mathrm{E}$ & 48977 & 2014 & Military \\
\hline Bodø & Norway & $67^{\circ} 16 \mathrm{~N}$ & $14^{\circ} 24 \mathrm{E}$ & 49731 & 2014 & Military \\
\hline Tiksi & Russia & $71^{\circ} 39 \mathrm{~N}$ & $128^{\circ} 48 \mathrm{E}$ & 50063 & 2014 & Maritime Transport \\
\hline Troms $\varnothing$ & Norway & $69^{\circ} 39 \mathrm{~N}$ & $18^{\circ} 57 \mathrm{E}$ & 71590 & 2014 & Administration \\
\hline
\end{tabular}

